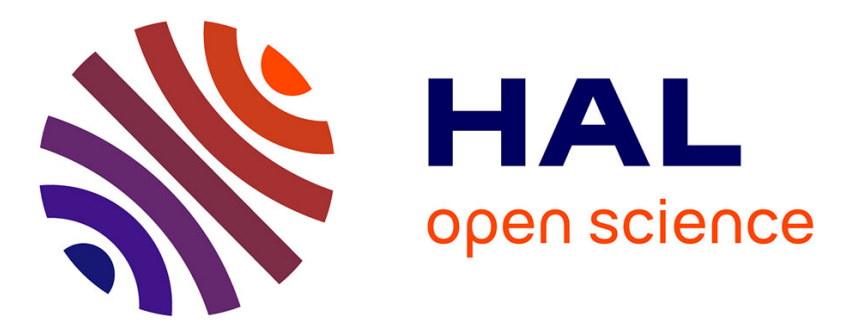

\title{
Strain localization and fluid infiltration in the mantle wedge during subduction initiation: Evidence from the base of the New Caledonia ophiolite
}

Mathieu Soret, Philippe Agard, Benoît Dubacq, A. Vitale-Brovarone, Patrick Monie, Alain Chauvet, H. Whitechurch, Benoît Villemant

\section{To cite this version:}

Mathieu Soret, Philippe Agard, Benoît Dubacq, A. Vitale-Brovarone, Patrick Monie, et al.. Strain localization and fluid infiltration in the mantle wedge during subduction initiation: Evidence from the base of the New Caledonia ophiolite. Lithos, 2016, 244, pp.1-19. 10.1016/j.lithos.2015.11.022 . hal-01306664

\section{HAL Id: hal-01306664 https://hal.science/hal-01306664}

Submitted on 9 May 2016

HAL is a multi-disciplinary open access archive for the deposit and dissemination of scientific research documents, whether they are published or not. The documents may come from teaching and research institutions in France or abroad, or from public or private research centers.
L'archive ouverte pluridisciplinaire HAL, est destinée au dépôt et à la diffusion de documents scientifiques de niveau recherche, publiés ou non, émanant des établissements d'enseignement et de recherche français ou étrangers, des laboratoires publics ou privés. 

subduction initiation: evidence from the base of the New Caledonia ophiolite

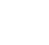

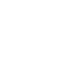

(1)

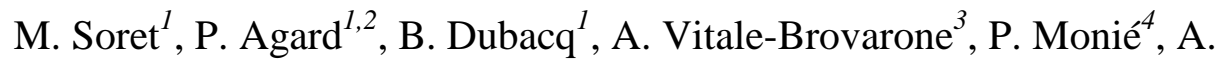

$$
\begin{aligned}
& \text { Chauvet }^{4}, \text { H. Whitechurch }{ }^{5}, \text { B. Villemant }{ }^{1}
\end{aligned}
$$


Despite decades of petrological and geochemical studies, the nature and

setting of obducted ophiolites remain controversial: the influence of supra-subduction zone environments on pre-existing oceanic lithosphere is yet to assess, and the processes leading to subduction/obduction initiation are still poorly constrained. Our study documents successive influx of slab-derived fluids and progressive strain localization within the upper mantle in a supra-subduction environment during the first few My of the subduction history. We focus on strongly sheared mafic amphibolites intruding peridotites near the mantle-crust transition of the New Caledonia obducted ophiolite and $\sim 50$ to $100 \mathrm{~m}$ above the basal thrust contact of the ophiolite. These $\mathrm{m}$ - to hm-long and several $\mathrm{m}$-thick shear bands are interpreted as inherited small-scale intrusions of mafic melts, probably dikes or sills, which were derived from a moderately refractory mantle source refertilized by supra-subduction zone fluids. ${ }^{40} \mathrm{Ar} /{ }^{39} \mathrm{Ar}$ age constraints on pargasite at ca. 90 Ma suggest that they could be inherited from the former Pacific west-dipping subduction.

Secondary deformation of these mafic intrusions is intimately associated to three major stages of fluid infiltration: (1) the first stage of deformation and metasomatism is marked by syn-kinematic growth of Ca-amphibole (at $700-800{ }^{\circ} \mathrm{C}$ and 3-5 kbar) with a distinctive supra-subduction zone signature, and controlled later channelization of aqueous fluids. ${ }^{40} \mathrm{Ar} /{ }^{39} \mathrm{Ar}$ dating on magnesio-hornblende indicates that this deformation episode occurred at ca. $55 \mathrm{Ma}$, coincident with east-dipping subduction initiation; (2) the main metasomatic stage, characterized by the development of a phlogopite-rich matrix wrapping peridotites and amphibolite boudins, points to the percolation of alkali-rich aqueous fluids at still high 
temperature $\left(650-750{ }^{\circ} \mathrm{C}\right) ;(3)$ the last, low temperature $\left(<600{ }^{\circ} \mathrm{C}\right)$ metasomatic stage results in the formation of deformed veinlets containing talc, chlorite and serpentine. (1)

\section{Introduction}

Obduction emplaces fragments of dense oceanic lithosphere on top of continents over several hundreds of kilometers (e.g. Oman, Newfoundland, Turkey, New Caledonia; Coleman, 1971). Despite numerous petrological and geochemical studies, the exact nature and setting of many obducted ophiolites remain unclear. The Oman ophiolite is a typical example where there are evidences for both a MORB-type signature (Boudier et al., 1988; Ceuleneer et al., 1988; Nicolas et al., 2000; Godard et al., 2000, 2003; Le Mée et al., 2004) and a supra-subduction zone (SSZ) geochemical imprint (Ernewein \&al, 1988, Stern and Bloomer, 1992; Shervais, 2001; McLeod et al., 2013).

The origin of obducted ophiolites has long been debated (Coleman, 1971, Dewey and Bird, 1971; Nicolas, 1989; Moores et al., 2000), with recent studies focusing on subduction-obduction initiation and early emplacement of ophiolites (Vaughan and Scarrow, 2003; Agard et al., 2007, 2014; Lagabrielle et al., 2013). Most of our knowledge on the initiation of the subduction-obduction system comes from the amphibolite to granulite facies metamorphic soles found at the base of most large-scale non-metamorphosed ophiolites and from magmatic dikes emplaced at different levels of the mantle sequence. These dikes generally record partial refertilization of the mantle wedge by subduction-derived fluids and show little deformation (e.g. Pirard, 2012; Xiong et al., 2014) whereas metamorphic soles are highly deformed portions of upper oceanic crust and sediments, heated and 
metamorphosed along the interface between the subducting slab and the hotter mantle wedge during early subduction (e.g. Wakabayashi and Dilek, 2003). Metamorphic soles typically predate the final emplacement of the ophiolite onto the continental margin by several millions of years ( 20 My for Oman; Agard et al., 2007).

We document sheared mafic amphibolite and feldspar-rich veins outcropping over a scale of hundreds of meters, within the peridotites of the New Caledonia ophiolite. They occur near the crust-mantle transition zone (e.g. Prinzhofer et al., 1980; Pirard et al., 2013) and 50 to $100 \mathrm{~m}$ above the basal contact of the ophiolite, south east of Noumea (Fig.1). As these deformed, metamorphosed rocks occur at the base of the New Caledonia ophiolite, it is tempting to relate them to subduction initiation, as for metamorphic soles. These sheared amphibolites could represent metamorphic sole fragments (outcropping in the Thio area; Cluzel et al., 2001, 2012) tectonically imbricated with basal peridotites, or be derived from melt products triggered by subduction-derived fluids (e.g. as the SSZ amphibole-bearing dikes in the Massif du Sud peridotites; Cluzel et al., 2006; Pirard, 2012; Pirard et al., 2013). Alternatively, they could also be inherited from earlier melting processes during ocean basin formation (e.g. near transform fault; Gaggero and Cortesogno, 1997; Constantin, 1999).

In this study, we provide a detailed petrological, geochemical and geochronological study to constrain the nature, the tectonic setting and the origin of these deformed amphibole-bearing dikes, and discuss implications for the New Caledonia subduction system in terms of geological setting and refertilization. 


\section{Geological setting}

New Caledonia is located at the northern termination of the Norfolk Ridge, a stretched continental fragment rifted off the eastern Australian margin during the Early Cretaceous rollback of the Western Pacific subduction zone and the opening of New Caledonia and Loyalty basins (Weissel and Hayes, 1977; Van de Beuque et al., 1998; Schellart et al. 2006).

The present-day structure of New Caledonia (Fig. 1a) results from a Paleogene episode of convergence. This event led to the closure of the South Loyalty Basin after the initiation of a north-east-dipping intra-oceanic subduction (Cluzel et al., 2001; Schellart et al., 2006; Matthews et al., 2015) and was responsible for the obduction of the New Caledonia ophiolite rooted in the Loyalty Basin (Collot et al., 1987). Geochronological and thermochronological data on mafic rocks from the metamorphic sole (Cluzel et al. 2012) and mafic dikes intruding the ultramafic ophiolite (Cluzel et al. 2006; Pirard, 2012) suggest that subduction inception occurred at ca. $56 \mathrm{Ma}$. At ca. $34 \mathrm{Ma}$, this intra-oceanic subduction led to the obduction of the South Loyalty Basin lithosphere toward the south-west onto the Norfolk Ridge (e.g. Paris, 1979; Prinzhofer, 1981; Collot et al., 1987).

The ophiolite complex of New Caledonia is composed of three allochtonous units of Cretaceous-Eocene age accreted over a calc-alkaline, island-arc derived basement (Fig.1a) (Aitchison et al., 1995; Cluzel et al., 2001). This basement was created from the Permian to the Early Cretaceous with the accretion of three major volcano-sedimentary terranes (i.e. Teremba, Boghen and Koh terranes) along the eastern Gondwana margin. Above this basement, the Tertiary subduction complex is composed of four main units: 
119 Caledonia (Fig.1a) made of volcano-sedimentary and mafic blueschist and eclogite

120 facies rocks, some of which are interbedded in a serpentinite matrix and minor

121 metasediments (Clarke et al., 1997; Carson et al., 2000; Cluzel et al., 2001; Vitale-

122 Brovarone and Agard, 2013). Mafic eclogites have Late Cretaceous to Eocene

123 protolith ages and share geochemical affinities with the Poya terrane (Cluzel et al.,

124 2001; Spandler et al., 2005)

2 - the Poya terrane, a weakly metamorphic mafic rocks unit (e.g. Eissen et al., 1998; Cluzel et al., 1997, 2001), outcrops along most of the west coast of New

127 Caledonia and also forms several isolated exposures along the eastern side (Fig.1a).

128 This terrane consists mainly of massive and pillow basalt, dolerite, and gabbro 129 associated with chert and volcaniclastic rocks (Eissen et al., 1998). The origin of the 130 Poya Terrane is controversial. Geochemical associations of back-arc basin and 131 enriched-MORB signatures constrain its formation to a back-arc environment (Cluzel 132 et al., 1997, 2001). Paleontological studies date its formation between 83 and $55 \mathrm{Ma}$

133 (Cluzel et al., 2001). This unit was interpreted as representing the crustal cover of the 134 South Loyalty Basin (Spandler et al., 2005; Lagabrielle et al., 2013), with the above 135 ages likely indicating the opening period of the basin.

1363 - the ultramafic ophiolite (named "Nappe des Péridotites") found on the 137 south-eastern portion of New Caledonia (Fig.1a) is constituted mainly of a $2-3 \mathrm{~km}$ 138 thick depleted mantle sequence (spinel-bearing harzburgite) above a 20 to $100 \mathrm{~m}$ 139 thick porphyroclastic serpentine mylonite. In the northern part of New Caledonia, 140 lherzolite is present in the Tiebaghi and the Poum massifs (e.g. Moutte, 1979; Ulrich 141 et al., 2010). This suite of ultramafic rocks is interpreted as representing upper mantle 142 rocks of the South Loyalty Basin (Lagabrielle et al., 2013) and documents a complex 
143 history with several supra-subduction zone settings, as attested by magmatic 144 intrusions.

In the Massif du Sud, Marchesi et al. (2009) and Pirard et al. (2013) reported gabbronorites and olivine gabbro sills at the top of ophiolitic sequence. These gabbros represent the lower crust of the ophiolite. They are separated from the underlying harzburgite by a dunite complex composed of dunite channels with the presence of dunite cumulates, wherlite, clinopyroxenite and websterite sills and dikes. Amphibole is commonly present in clinopyroxenite bodies but absent from the lower crust gabbronorites (Pirard, 2012; Pirard et al., 2013). These authors interpret this complex as the crust-mantle transition with mafic sills and dikes being the result of percolating, hydrous primitive arc magmas within the peridotite during early stages of the subduction system and nascent arc crust formation.

The Massif du Sud is also extensively cross-cut by Early Eocene felsic, anhydrous and hydrous coarse grained dikes (leucodiorite, granitoid, micro-diorite, dolerite and hornblendite; Prinzhofer, 1981; Cluzel et al., 2005, 2006; Pirard, 2012; Pirard et al., 2013) discordant with the harzburgite and/or the gabbro sills from the lower crust. These dikes are generally unmetamorphosed and undeformed with the exception of few diorite dikes which are boudinaged, locally micro-folded and where amphibole shows a preferred orientation (Cluzel et al., 2012). Upon geochemical and geochronological features, these dikes have been interpreted as formed in a suprasubduction zone setting. These dikes are essentially considered as synchronous or immediately posterior to magma injection in active faults that formed during the first stages of the 55 Ma subduction (Cluzel et al., 2006, 2012). However, Prinzhofer (1981) obtained 2 different K-Ar ages (i.e. $90 \pm 10 \mathrm{Ma}$ and $42 \pm 5 \mathrm{Ma}$ ) for dolerite dikes intruding the Massif du Sud. The youngest dikes coincide with the Eocene New 
168 Caledonia subduction. The Late Cretaceous dikes could be an evidence of the ocean 169 spreading stage of the South Loyalty Basin (Prinzhofer, 1981; Matthews et al., 2015).

170 The Late Cretaceous age of $85 \mathrm{Ma}$ was also measured in zircon cores from the high-

171 pressure Pouebo unit (Spandler et al., 2005). In addition, Cluzel et al. (2005) report

172 granitoid dikes intruding the Massif du Sud at 27 and 24 Ma. They interpret these

173 dikes, coeval with the final obduction stages, as related to the inception of a new

174 subduction along the west coast of New Caledonia in response to the blocking of the

175 previous Eocene subduction. Altogether these dikes appear to record several

176 subduction-related events, suggesting that the ophiolite witnesses several and

177 distinctive stages of migration, accumulation and re-equilibration of different melts

178 (including hydrous melts) in a supra-subduction environment (e.g. Marchesi et al.,

179 2009; Ulrich et al., 2010; Pirard, 2012), rather than being the result of a fractional

180 crystallization from a single magma-type during oceanic spreading (Prinzhofer and 181 Allègre, 1985). 4 - an amphibolite to granulite facies metamorphic sole is found in places

183 between the ophiolite and the Poya and Pouebo underlying terranes (Cluzel et al., 184 2012). This metamorphic sole is interpreted to have been welded to the ophiolite 185 during subduction inception. Using various thermobarometers, Cluzel et al. (2012) 186 estimate peak crystallization conditions around $5 \mathrm{kbar}$ and 800 to $950{ }^{\circ} \mathrm{C}$. 187 Thermochronology on hornblende $\left({ }^{40} \mathrm{Ar} /{ }^{39} \mathrm{Ar}\right)$, zircon and sphene (U-Pb) indicate that 188 these mafic rocks crystallized at ca. 56 Ma (Cluzel et al., 2012). This result and 189 inferred pressure-temperature conditions for the New Caledonia metamorphic sole 190 give a geothermal gradient greater than $40{ }^{\circ} \mathrm{C} / \mathrm{km}$, consistent with subduction 191 inception occurring at or near the spreading ridge of the South Loyalty Basin. 


\section{Outcrop-scale deformation patterns and mineralogy}

The study area is exposed at low tide on the foreshore of Plum Beach (southeast of Noumea), across a $\sim 150 \times 100 \mathrm{~m}$ surface (Fig. 1b). This area is bounded to the west by the New Caledonia Basin and by a densely vegetated cliff to the east. It is located near the base of the ophiolite, 50 to $100 \mathrm{~m}$ above the north-east dipping contact with the underlying Poya unit, which outcrops $2 \mathrm{~km}$ to the north.

The study area is a major deformation zone characterized by large-scale mafic shear bands (up to $100 \mathrm{~m}$ long in places) and centimetric to decimetric orthopyroxenite veins away from the deformed area. The shear bands and veins crosscut the peridotite, which is constituted mainly of highly serpentinized harzburgite and rare dunite. One to two meters away from the shear bands, the peridotite is massive and has only a tectonite porphyroclastic texture with a high temperature foliation steeply dipping to the NE (parallel to the paleo-Moho according to Prinzhofer et al., 1980). The orientation of this foliation is discordant with respect to the deformation observed in the mafic shear bands.

Ten major shear bands have been recognized in the study area. Shear bands \#1 to \#7 are 30 to $50 \mathrm{~m}$ long and strike $\sim \mathrm{N} 150$ (Fig. 1b). They disappear under the eastern cliff but likely extend further to the south-east, where similar shear bands are found in apparent continuity along the coast (\#8 to \#10). The overall length of these shear bands is thus greater than $150 \mathrm{~m}$.

The shear bands are $\mathrm{m}$ - to several m-thick and commonly outlined by $10-50 \mathrm{~cm}$ thick amphibolite bands, mostly found at the core of the shear bands (and, when found on the margins, only on their south-west side; Fig. 2). 
Peridotite and amphibolite are strongly boudinaged within the amphibolitebearing shear zones (Fig. 3a,b,c). Strain increases towards the core of the shear bands, as shown by the marked decrease in boudin size, from the $\mathrm{m}$ - to the $\mathrm{cm}$ - scale. Both ultramafic and mafic boudins are sigmoidal and indicate consistent sinistral-reverse, 220 top to the north-west shear senses across the whole outcrop (Fig. 2,3a). These boudins 221 are embedded in a phlogopite-rich matrix described below.

A network of distributed leucocratic feldspar-rich veins also cross-cuts the peridotite. This network is mainly found on the margins of the high strain bands.

224 Mutual cross-cutting relationships between the dark amphibolites and the feldsparrich veins suggest that they formed coevally. The vein network is developed only on one side of the amphibolite bands (to the NE); the density, thickness and length of the veins decrease away from the amphibolites (Fig. 3c,d,f,g). The mafic shear band \#4bis is a dm-thick dark amphibolite without feldspar-rich veins (Fig. 2). vol.\% plagioclase, variably altered to reddish-to-yellowish low-grade oxidized 231 aggregates. Pyroxene (always orthopyroxene, as detailed below) amounts to 15-30 232 vol. $\%$.

Leucocratic feldspar-rich veins are characterized by a predominance of 234 plagioclase with up to 20 vol.\% coarse-grained orthopyroxene crystals (Fig. 4a,b). 235 Most orthopyroxenes are rimmed by calcic-amphibole.

A light colored, green to grey matrix comprising phlogopite, chlorite, talc and 237 serpentine is observed within the shear bands and appears to form at the expense of 238 both the mafic and ultramafic rocks (Fig. 3c,d,e,f). Late, milky white cm-thick serpentine veinlets rim peridotite boudins and also cross-cut the boudins and the 
matrix. Phlogopite is also observed concentrated in m-scale veins next to some of the

241 shear bands (\#9).

\section{Sampling strategy and analytical techniques}

60 samples (Table 1) were collected in the field across the whole range of 246 textures and mineralogical assemblages of the shear bands (both for mafic -M- and 247 ultramafic -UM- protoliths; Fig. 2). 15 samples are dark amphibolites, either within 248 deformation bands (e.g. M4d; Fig. 2,5a) or isolated in undeformed peridotite (e.g. 249 M8a), whereas 5 samples are deformed feldspar-rich mafic veins (e.g. M8e; Fig. 5b), 250 including an undeformed feldspar-rich veinlet isolated in peridotite (sample M9). 251 Ultramafic samples comprise 17 peridotite boudin samples surrounded by deformed 252 feldspar-rich veins and phlogopite-rich matrix (e.g. UM13, UM10; Fig. 5c,d), 14 253 undeformed peridotite samples (e.g. UM12, UM14) and one orthopyroxenite vein 254 sample.

EPMA was carried out at CAMPARIS (UPMC-IPGP, Paris, France) on 258 amphibolites $(n=7)$, feldspar-rich veins $(n=5)$, peridotite boudins $(n=5)$, undeformed 259 peridotites $(n=2)$ and on the biotite-rich matrix $(n=7)$, using classical analytical 260 conditions for spot analyses (1-2 $\mu \mathrm{m}$ spot size; $15 \mathrm{kV}, 10 \mathrm{nA}$, wavelength-dispersive 261 spectroscopy mode), using $\mathrm{Fe}_{2} \mathrm{O}_{3}(\mathrm{Fe}), \mathrm{MnTiO}_{3}(\mathrm{Mn}, \mathrm{Ti})$, diopside $(\mathrm{Mg}, \mathrm{Si}), \mathrm{CaF}_{2}(\mathrm{~F})$, 
orthoclase $(\mathrm{Al}, \mathrm{K})$, anorthite $(\mathrm{Ca})$ and albite $(\mathrm{Na})$ as standards for bracketed elements. Representative analyses are given in Table 2.

\subsection{Thermobarometry}

Pressure and temperature conditions of crystallization have been estimated using the hornblende-plagioclase geothermobarometer of Holland and Blundy (1994) modified by Anderson and Smith (1995) in three olivine-bearing amphibolites and in six olivine-free amphibolites. This geothermobarometer is based on the reaction:

270 edenite + albite $=$ richterite + anorthite. The absence of Ti-rich phases in amphibolites

271 invalidates the use of Ti-based geothermobarometers. Representative pressure272 temperature estimates are given in Table 2.

The $\mathrm{Fe}^{3+}$ estimation method in amphibole given in Holland and Blundy (1994) 274 provides the minimum $\left(\mathrm{Fe}^{3+} / \mathrm{Fe}_{\text {tot }}\right)$ ratio for which sufficient $\mathrm{Na}$ is allocated to the $\mathrm{A}$ 275 site. $\mathrm{Fe}^{3+} / \mathrm{Fe}_{\text {tot }}$ here averages around 0.4 in late amphibole (i.e. magnesio-hornblende). 276 With a $\left(\mathrm{Fe}^{3+} / \mathrm{Fe}_{\text {tot }}\right)$ ratio $=1$, estimated after the method of Leake et al. (1997), the 277 estimated temperature is $\sim 70{ }^{\circ} \mathrm{C}$ higher than that calculated with $\mathrm{Fe}^{3+} / \mathrm{Fe}_{\text {tot }}=0.4$.

\subsection{ICPMS and LA-ICPMS:}

Whole-rock major element analysis was performed on 7 samples (Table 3) at 281 EOST in Strasbourg, France, by ICP-AES and ICP-MS (see Table 2; analytical 282 procedure given in Omrani et al., 2008) and at UPMC Univ. Paris 6 (following the 283 procedure of Salaün et al. 2010). 
out using a $10 \mathrm{~Hz}$ laser repetition rate and $50 \mu \mathrm{m}$ beam diameter for amphibole. All analyses were conducted at fixed beam position. For internal standardization ${ }^{43} \mathrm{Ca}$ was used for amphibole. For external standardization, NIST SRM 610 and 612 glasses were used after Pearce et al. (1997). Raw data were processed using GLITTER

290 (GEMOC, Macquarie University, Australia). The following masses were analyzed 291 (Table 4): ${ }^{7} \mathrm{Li},{ }^{11} \mathrm{~B},{ }^{47} \mathrm{Ti},{ }^{85} \mathrm{Rb},{ }^{88} \mathrm{Sr},{ }^{89} \mathrm{Y},{ }^{90} \mathrm{Zr},{ }^{93} \mathrm{Nb},{ }^{133} \mathrm{Cs},{ }^{138} \mathrm{Ba},{ }^{139} \mathrm{La},{ }^{140} \mathrm{Ce},{ }^{141} \mathrm{Pr}$, ${ }^{146} \mathrm{Nd},{ }^{147} \mathrm{Sm},{ }^{153} \mathrm{Eu},{ }^{157} \mathrm{Gd},{ }^{159} \mathrm{~Tb},{ }^{169} \mathrm{Dy},{ }^{165} \mathrm{Ho},{ }^{166} \mathrm{Er},{ }^{172} \mathrm{Yb},{ }^{175} \mathrm{Lu},{ }^{178} \mathrm{Hf},{ }^{181} \mathrm{Ta},{ }^{208} \mathrm{~Pb}$, ${ }^{238} \mathrm{U},{ }^{232} \mathrm{Th}$.

\subsection{Radiometric dating}

The selected samples were crushed and sieved; single grains of amphibole were handpicked under binocular microscope and cleaned in ultrasonic bath with acetone and distilled water. They were packaged in $\mathrm{Al}$ foils and irradiated for 40 hours in the core of the Triga Mark II nuclear reactor of Pavia (Italia) with several aliquots of the Fish Canyon sanidine standard (28.03 $\pm 0.08 \mathrm{Ma}$; Jourdan and Renne, 2007) as flux monitor. Argon isotopic interferences on $\mathrm{K}$ and $\mathrm{Ca}$ were determined by irradiation of

$302 \mathrm{KF}$ and $\mathrm{CaF}_{2}$, pure salts from which the following correction factors were obtained:

$\left({ }^{40} \mathrm{Ar} /{ }^{39} \mathrm{Ar}\right)_{\mathrm{K}}=0.00969 \pm 0.00038,\left({ }^{38} \mathrm{Ar} /{ }^{39} \mathrm{Ar}\right)_{\mathrm{K}}=0.01297 \pm 0.00045,\left({ }^{39} \mathrm{Ar} /{ }^{37} \mathrm{Ar}\right)_{\mathrm{Ca}}=$

$0.0007474 \pm 0.000021$ and $\left({ }^{36} \mathrm{Ar} /{ }^{37} \mathrm{Ar}\right)_{\mathrm{Ca}}=0.000288 \pm 0.000016$. Argon analyses were performed at Géosciences Montpellier (France) with two analytical devices that each consist of: (a) an IR-CO2 laser of $100 \mathrm{kHz}$ used at 5-15\% during $60 \mathrm{sec}$, (b) a

307 lenses system for beam focusing, (c) a steel chamber, kept at $10^{-8}-10^{-9}$ bar, with a 308 drilled copper plate, (d) an inlet line for purification of gases including two $\mathrm{Zr}$-Al 309 getters, (e) a multi-collector mass spectrometer (Argus VI from Thermo-Fisher) or an 
310 MAP215-50 single collector mass spectrometer depending on the used device. A

311 custom-made software controls the laser intensity, the timing of

312 extraction/purification and the data acquisition. To measure the Ar background within

313 the system, one blank analysis was performed every three sample analyses.

314 ArArCalc $@$ v2.5.2 was used for data reduction and plotting. The one-sigma errors

315 reported on plateau, isochron and total gas ages include the error on the irradiation

316 factor J. Atmospheric ${ }^{40} \mathrm{Ar}$ was estimated using a value of the initial ${ }^{40} \mathrm{Ar} /{ }^{36} \mathrm{Ar}$ of

317 295.5. Data are portrayed as age spectra on figure 11 and summarized in Table 5.

\section{Petrography}

\subsection{Mafic rocks}

Dark mafic bands (Fig. 6a,b,c) contain abundant amphibole (40-70 vol.\%), plagioclase (10-50 vol.\%), orthopyroxene (10-20 vol.\%) \pm olivine (0-25 vol.\%).

323 Olivine is only found in some mafic layers (i.e. shear band \#4bis; M8a, Fig. 6c). No 324 clinopyroxene is found. Sulphide inclusions in amphibole, iron oxides and rare apatite 325 (samples M8a and M8b) are also present.

326 Amphibole surrounds all other mineral phases and appears texturally as a late 327 crystallization product with respect to olivine, orthopyroxene (Fig. 6d,e,g, 7a,b,c,d). 328 Sample M8a show two distinct amphibole-bearing layers as an olivine-free 329 amphibolite vein cross-cut a boudinaged olivine-bearing amphibolite band (Fig 6c). In 330 olivine-bearing amphibolites (shear band \#4bis), amphibole (referred to as early 331 amphibole) is strongly pleochroic from blue to green under the microscope with a 332 sub-automorph habitus and marked cleavages (Fig. 6d,g). By contrast, amphibole in 
333 olivine-free amphibolite (referred to as late amphibole) shows a distinctly paler

334 pleochroism and presents a higher degree of deformation (Fig. 6e).

335 Textural relationships between plagioclase, orthopyroxene and olivine are 336 obscured by the amphibolitization stage. Olivine appears as fine-grained clusters 337 closely associated with, and generally included in, orthopyroxene (Fig. 6g, 7a,b). In 338 sample M4e, olivine was replaced by orthopyroxene before the crystallization of large 339 amphibole grains (Fig. 7c,d). Olivine is also partially destabilized by tremolite.

340 Primary Cr-rich spinel crystals are present in olivine (Fig. 7a). In olivine-bearing 341 samples, plagioclase is rare and partially to totally replaced by amphibole (Fig. 6g).

342 Leucocratic feldspar-rich veins are mainly composed of plagioclase (70-100\%) 343 with subordinate orthopyroxene (0-20\%) and rare amphibole (0-10\%). Undeformed 344 leucocratic veins show euhedral amphibole in a groundmass of large plagioclase 345 crystals (Fig. 6f). Close to the shear bands, veins of plagioclase evidence deformation 346 and grain size reduction. Orthopyroxene is only partially preserved yet retaining 347 textural evidence of former equilibrium with plagioclase. Orthopyroxene is included 348 in amphibole or rimmed by amphibole pressure shadows (Fig. 6e), again suggesting 349 the partial destabilization of coarse grained primary assemblage of orthopyroxene $( \pm$ 350 olivine) and plagioclase to form various generations of amphibole. A network of late 351 serpentine, chlorite and talc is observed in orthopyroxene fractures (Fig. 6d).

As for ultramafic rocks, mafic bands are locally replaced by a phlogopite-rich 353 matrix (in which phlogopite is in turn replaced by chlorite). Orthopyroxene and 354 calcic-amphibole appear only as relicts into layers of phlogopite and acicular orthoamphibole. Plagioclase is destabilized and rimmed by a Ba-rich K-feldspar. 
The mineralogy of undeformed peridotites is dominated by an isotropic network of serpentine (75-90\%), with rare relicts of brown orthopyroxene, olivine phenocrysts and black chromiferous spinels. These peridotites belong to the highly depleted 361 harzburgites of the Massif du Sud (i.e. Prinzhofer and Allègre, 1985; Ulrich et al., 362 2010; Pirard et al., 2013). Few deformation textures are observed, where the extensive 363 late serpentinization may have erased former deformation textures. assemblage. However, a reaction rim around peridotite boudins contains coarse-

366 grained hornblende pseudomorphing orthopyroxene, and containing chromite 367 inclusions (Fig. 7g). Light colored phlogopite (Fig. 7b,f,h) and acicular ferro368 magnesian ortho-amphibole (Fig. 5f) co-crystallized around peridotite boudins as a 369 result of the partial destabilization of ultramafic orthopyroxene and secondary 370 hornblende. Therefore, this assemblage postdates the boudinage of the peridotite and 371 the first hydration recorded by the crystallization of hornblende. Phlogopite increases 372 in modal proportion towards the amphibole-rich mafic bands, along with a grain size 373 decrease but shows no preferred orientation. Chlorite is interlayered with phlogopite 374 and crystallizes as a late stage alteration product responsible for the macroscopically 375 greenish to greyish color of the matrix. Millimetric veinlets of talc-chlorite376 serpentine, slightly sheared in places, also cross-cut peridotites boudins (Fig. 7h). 377 These veinlets are themselves cross-cut by a late isotropic serpentine network.

\section{Mineralogy}


$382 \pm 0.02$ (Fig. 8a). In mafic rocks, the Mg\# of orthopyroxene shows lower values 383 ranging between 0.77 and 0.85 .

$384 \quad \mathrm{Cr}_{2} \mathrm{O}_{3}$ and $\mathrm{CaO}$ contents (Fig. 7a) show small yet systematic variations between 385 the mafic bodies, with higher values in olivine-bearing rocks $\left(<0.20 \mathrm{wt} \% \mathrm{Cr}_{2} \mathrm{O}_{3}\right.$; $3860.35-0.65$ wt\% $\mathrm{CaO}$, except for three points with 0.82 and $0.97 \mathrm{wt} \% \mathrm{CaO}$ ) than in 387 leucocratic feldspar-rich rocks $\left(<0.04\right.$ wt $\left.\% \mathrm{Cr}_{2} \mathrm{O}_{3} ; 0.15-0.35 \mathrm{wt} \% \mathrm{CaO}\right) . \mathrm{Cr}_{2} \mathrm{O}_{3}$ and $388 \mathrm{CaO}$ contents are higher in ultramafic rocks, with large intra-sample variations $(0.40$ $\left.3890.80 \mathrm{wt} \% \mathrm{Cr}_{2} \mathrm{O}_{3} ; 0.40-1.80 \mathrm{wt} \% \mathrm{CaO}\right)$. $\mathrm{Al}$ contents are low ( 0.02 p.f.u.) and show no 390 systematic variation.

Orthopyroxene in harzburgite falls within the composition domain of 392 orthopyroxene-poor harzburgite described by Prinzhofer et al. (1980) and Pirard et al. 393 (2013; Fig. 8a). Orthopyroxene in olivine-bearing and olivine free amphibolites 394 overlaps the range of orthopyroxene in amphibolite and hornblendite dikes described 395 by Pirard (2012). Orthopyroxene in mafic bands have similar Mg\# orthopyroxene 396 from gabbronorite sills of Pirard et al. (2013), but show lower Ca content.

\section{Olivine}

The patterns of Mg\# of olivine (Fig. 8b) in harzburgite and in olivine-bearing 400 mafic rocks mirror those of orthopyroxene described above (Fig. 8b). Mg\# in 401 ultramafic olivine is $0.91-0.92$ and the $\mathrm{MnO}$ content varies between 0.06 and 0.22 402 wt\% (Fig. 8b), in the same range as those of nearby harzbugites (Pirard et al., 2013). 403 Olivine in mafic bands shows similar $\mathrm{Mg \#}(0.78-0.85 \mathrm{wt} \%)$ to amphibolite and 404 hornblendite dikes of Pirard (2012). The Mg\# is lower and the $\mathrm{MnO}$ content $(0.20-$ 
$0.39 \mathrm{wt} \%$ ) is higher than reported for mafic cumulates by Pirard et al. (2013; Fig. 8b). $\mathrm{NiO}$ content in mafic olivine varies between 0.16 and $0.21 \mathrm{wt} \%$, which is consistent with the most evolved olivine found in olivine-bearing cumulates (Pirard et al., 2013). Compositional trends in $\mathrm{NiO}$ and $\mathrm{MnO}$ vs. $\mathrm{Mg \#}$ match the fractional crystallization trends evidenced by Pirard et al. (2013).

\section{Feldspar}

Plagioclase occurs only in mafic rocks, as veins in leucocratic feldspar-rich rocks (with a composition of a norite), or as scarce, isolated crystals in olivine-bearing rocks. In noritic rocks, albite content $[\mathrm{Na}=\mathrm{Na} /(\mathrm{Na}+\mathrm{Ca})]$ ranges from 0.46 to 0.66 (from labradorite to andesine; Fig. 8c), in the domain of amphibolite dikes described by Pirard (2012). In olivine-bearing rocks, plagioclase corresponds to anorthite (Na\#: 0.02-0.07; Fig. 8c), in the range of amphibolite dikes of Pirard (2012). Secondary feldspar rimming norite veins are rich in alkalis $\left(\sim 5.5\right.$ wt $\% \mathrm{Na}_{2} \mathrm{O} ; \sim 3.5$ wt $\% \mathrm{~K}_{2} \mathrm{O}$; $\sim 12.5 \mathrm{wt} \% \mathrm{BaO}$ ) and have intermediate composition between anorthoclase and hyalophane.

\section{Ca-amphibole}

Amphibole shows Mg\# comparable to that of orthopyroxene and olivine in both mafic (0.90-0.74; Fig. 9a) and ultramafic rocks $(\sim 0.91 \pm 0.01$; Fig. 9a), and $\mathrm{Na}<0.5$ p.f.u. and $(\mathrm{Ca}+\mathrm{Na})_{\mathrm{B}}>1.0$ p.f.u. typical of calcic-amphibole (Leake et al., 1997).

In olivine-bearing mafic bodies, early amphibole is pargasitic with $(\mathrm{Na}+\mathrm{K})_{\mathrm{A}} \geq$ 0.5 p.f.u and $\mathrm{Si}$ ranging from 6.12 to 6.30 p.f.u. (Fig. 9b). Late amphibole destabilizing this pargasite hornblende has $(\mathrm{Na}+\mathrm{K})_{\mathrm{A}} \leq 0.5$ p.f.u. and a higher $\mathrm{Si}$ 
content (6.50-7.00 p.f.u.; Fig. 9b), and belongs to the magnesio-tschermakite 430 hornblende (Leake et al., 1997). In olivine-free samples (i.e M3c), late amphibole 431 shows a decrease in $(\mathrm{Na}+\mathrm{K})_{\mathrm{A}}$ and an increase of the Si content (6.37-6.88 p.f.u.; Fig. 432 9b). This evolution is also observed with the content in $\mathrm{Ti}(0.15-0.05$ p.f.u.). This 433 composition is similar to the composition of amphibole from undeformed mafic dikes 434 described by Pirard (2012), and partially fall in the domain of the metamorphic sole amphibolites from Thio considering their $\mathrm{Ti}$ and $(\mathrm{Na}+\mathrm{K})_{\mathrm{A}}$ contents, yet with a much 436 lower Mg\# (see Cluzel et al., 2012). p.f.u) and does not fall in the domains of amphibole-bearing dikes (Pirard, 2012) or of the metamorphic sole (Cluzel et al., 2012) (Fig. 9c). Amphibole with the highest Si content is again the poorest in $(\mathrm{Na}+\mathrm{K})_{\mathrm{A}}$ content (Fig. 9b). Tremolite is only present in 441 olivine-bearing rocks and texturally associated to mafic olivine (Fig. 9b).

Late acicular amphibole crystallizing within the phlogopite-rich matrix belongs 446 to the ferro-magnesian anthophyllite series ( $\mathrm{Si} \sim 8$ p.f.u; $\mathrm{Al}_{\text {tot }} \leq 0.23$ p.f.u.; $(\mathrm{Ca}+\mathrm{Na})_{\mathrm{B}}$ $447 \leq 0.15$ p.f.u.; Leake et al., 1997).

\section{Phlogopite}

Phlogopite presents a Mg\# of 0.89 , regardless of its structural position in the 451 shear band (Table 1). Only few crystals display the $\mathrm{K}_{2} \mathrm{O}$ content of a regular mica 
452

453

454

455

456

457

458

459

460

461

462

463

464

465

owing to retrogression by chlorite. $\mathrm{Cr}_{2} \mathrm{O}_{3}(<0.02 \mathrm{wt} \%)$ and $\mathrm{TiO}_{2}(0.05 \mathrm{wt} \%)$ are present in small amounts.

\section{Accessory minerals}

Early amphibole grains (i.e. pargasite) host various inclusions (e.g. spinel, magnetite, sulfides). Magnetite inclusions derive from the oxidation of iron-sulphide and spinel. Spinel in harzburgite is a chromite with a $\mathrm{Cr} \#\left[\mathrm{Cr} \#=\left(\mathrm{Cr} /\left(\mathrm{Cr}+\mathrm{Al}+\mathrm{Fe}^{3+}\right)\right]\right.$ of $0.72 \pm 0.05$ and a Mg\# of $0.35 \pm 0.05$ (Fig. $9 \mathrm{~d}$ ). Spinel is consistently more aluminous in mafic rocks, with a $\mathrm{Cr} \#$ from 0.18 to 0.38 for a $\mathrm{Mg \#}$ varying between 0.25 and 0.32 (Fig. 9d). $\mathrm{TiO}_{2}$ in mafic and ultramafic spinel is below the detection limit. $\mathrm{Cu}$ - and Ni-rich Fe-sulphides (i.e. pentlandite-pyrrhotite) are found as inclusions in early amphibole in olivine-bearing mafic rocks.

\section{Geochemistry}

\section{7a. Whole rock geochemistry}

Rare earth elements (REE) normalized to N-MORB of both olivine-bearing and olivine-free amphibolites display values lower than $1\left[(\mathrm{REE})_{\mathrm{N}} \sim 0.4\right]$, with the exception of the sample M4f $\left.\left[(\mathrm{REE})_{\mathrm{N}} \sim 1\right)\right]$ (Fig. 10a). They display a slight enrichment in light REE (LREE) relative to heavy REE $(\mathrm{HREE})\left[(\mathrm{La} / \mathrm{Lu})_{\mathrm{N}}=1.89 \pm\right.$ 0.35]. High field strength elements (HFSE; Ti, Hf, Zr, Nb, Ta) are slightly depleted relative to $\mathrm{REE}\left[(\mathrm{Nb} / \mathrm{Lu})_{\mathrm{N}}=0.41 \pm 0.05\right]$ (Fig. 10a). Large Ion Lithophile Elements (LILE; Pb, U, Th, Ba, Rb, Cs) show large enrichments relative to REE, increasing with their degree of mobility and incompatibility $\left[(\mathrm{Cs} / \mathrm{Lu})_{N}=62 \pm 39\right]$ (Fig. 10a). 

similar pattern to amphibolites though slightly shifted towards higher values by a 477 factor of $\sim 2$ (Fig. 10a). Gabbronorite sills (Pirard et al., 2013) are highly depleted in 478 all incompatible elements. However, they display a pattern roughly similar to that of 479 amphibolites, with a mean relative depletion factor of $\sim 10$ but with larger $\mathrm{Pb}$ and $\mathrm{Sr}$ 480 relative anomalies (Fig. 10a). Arc tholeiitic dikes (Cluzel et al., 2006) have 481 incompatible elements compositions overlapping with those amphibolites (Fig. 10a). 482 It strongly suggests that tholeiitic dikes and amphibolites have a same origin.

In phlogopite-rich rocks, concentrations in HREE are similar to those of olivine-

484 free and olivine-bearing amphibolite (Fig. 10a). However, phlogopite-rich rocks have 485 a larger enrichment in LREE relative to $\operatorname{HREE}\left[(\mathrm{La} / \mathrm{Lu})_{\mathrm{N}}=3.55 \pm 1.77\right]$. These rocks are depleted in HFSE relative to REE but less depleted than olivine-bearing and olivine-free amphibolite (with the exception of the sample M4f). Sr shows a large depletion relative to REE and LILE display a large enrichment especially in Cs.

\section{7b. In-situ trace elements}

Incompatible trace elements compositions of early and late amphibole, respectively found in olivine-bearing and olivine-free amphibolites display similar N-

493 MORB normalized patterns (Fig. 10b) with however slightly higher content in late amphibole (i.e. magnesio-hornblende) compared to early amphibole (i.e. pargasite). REE patterns from heavy REE (HREE) to light REE (LREE) are flat and close to N-

496 MORB values, with $(\mathrm{La} / \mathrm{Lu})_{\mathrm{N}}=0.87 \pm 0.39$. HFSE are slightly depleted relative to $497 \operatorname{REE}\left[(\mathrm{Nb} / \mathrm{Lu})_{\mathrm{N}}=0.21 \pm 0.07\right]$. LILE show positive anomalies $\left[(\mathrm{Cs} / \mathrm{Lu})_{\mathrm{N}}=12.1 \pm\right.$ 498 5.9]. Overall, similar behaviors (i.e. negative anomalies in HFSE and positive 
anomalies in LILE) are observed in whole-rock data on amphibolites and in-situ data on amphibole, suggesting that the trace element budget in the rocks is mainly

501 controlled by amphibole. However, higher HREE content in late amphibole compared 502 to that in early amphibole is difficult to explain with a fluid mediated 503 recrystallization. This higher content more likely mirrors the more differentiated 504 nature of the norite dikes compared to the troctolite dikes (prior to metamorphic 505 hydration).

Amphibole in mafic amphibole-bearing dikes analyzed by Pirard (2012)

507 displays a pattern similar to that of the amphibole reported here (grey overlay; Fig. 508 10b): it shows a similar enrichment in $\mathrm{Pb}$ and depletions in $\mathrm{Ti}-\mathrm{Sr}-\mathrm{Nb}-\mathrm{Ta}$ with 509 comparable absolute values, including in the most mobile and incompatible trace 510 elements, advocating for similar origins. Ba-content is similar in both analyses series 511 and Rb-content is lower in the amphibole of Pirard (2012) than all our early and late 512 amphiboles (Fig. 10b). Cs has not been measured.

\section{8. ${ }^{40} \mathrm{Ar} /{ }^{39} \mathrm{Ar}$ constraints on mafic rocks formation}

${ }^{40} \mathrm{Ar} /{ }^{39} \mathrm{Ar}$ laser probe step-heating dating was carried out on 20 isolated single

516 amphibole crystals from 11 different rocks, using the procedure described above.

517 These samples are mainly olivine-free and olivine-bearing amphibolites from the

518 Plum beach. They also include amphibolites from the Thio metamorphic sole (sample 519 C10) and undeformed gabbroic dikes from the Massif du Sud (samples SNC03 and 520 SNC04, col des Deux Tétons). Age spectra and inverse isochron plots are reported on

521 figure 11 for some of these samples. The closure temperature for the ${ }^{40} \mathrm{Ar} /{ }^{39} \mathrm{Ar}$ 522 method in hornblende is around $550 \pm 50{ }^{\circ} \mathrm{C}$ (Harrison, 1981). For most samples, 
errors are relatively large due to the fact that only one grain was analyzed each time and that the $\mathrm{K}$ content (and therefore the amount of radiogenic Ar) is low in these amphiboles.

Amphibole from the Thio metamorphic sole provides an age of $56.9 \pm 2.6 \mathrm{Ma}$ (Fig. 11a,12) consistent with the age reported by Cluzel et al. (2012) from a nearby exposure. Similar ages are obtained on the two undeformed gabbros from the Massif $\mathrm{du}$ Sud for which intercept ages are in the range 51-52 \pm 4 Ma (Fig. 11a,12; see the Online Fig. S1 for isotope correlation plot), with initial ${ }^{40} \mathrm{Ar} /{ }^{36} \mathrm{Ar}$ values close to the present-day atmospheric ratio (see Table 5). Large amphibole from a partially weathered pegmatite dike yields more scattered results with some evidence of excess argon as a result of fluid infiltration and only a maximum age of $60 \pm 5$ Ma can be attributed to this sample.

At Plum beach, 8 hornblende crystals from 4 olivine-free amphibolites (M3d, M4d, M8a-Z2, M8f) and 5 hornblende crystals from two weakly deformed olivinebearing amphibolite (M15 and M8a-Z1) yield ages ranging between 54 and 93 Ma, with the exception of one crystal (M15) that displays a strongly discordant age pattern and an integrated age of $167 \pm 21$ Ma likely related to trapped excess argon. For M8f, 4 amphiboles were analyzed and representative age spectra are shown on figure $11 \mathrm{~b}$, with plateau dates ranging from $54.9 \pm 2.0 \mathrm{Ma}$ to $59.2 \pm 2.7 \mathrm{Ma}$ and a similar age in the isotope correlation plot with an initial atmospheric ratio (reported in the Online Fig. S1). The consistency of the results on 4 grains from M8f and the lack of evidence of excess argon for this sample suggest that amphibolitisation and related deformation occurred at ca. $55 \mathrm{Ma}$, which is supported by the age of $54.1 \pm 3.4 \mathrm{Ma}$ obtained on amphibolite M3b from another shear zone. According to microprobe analyses and textural observations, it is likely that this age of ca. $55 \mathrm{Ma}$ corresponds to the 
crystallization of secondary magnesio-hornblende that partially replaced pargasite and

549 orthopyroxene. This age range coincides with the formation of the metamorphic sole 550 at Thio (sample C10 and Cluzel et al., 2012), the emplacement of some gabbros 551 (samples SNC03 and SNC04) and pre-obduction felsic dikes (53 Ma; Cluzel et al., 552 2006).

8 amphiboles from 5 olivine-bearing samples yield older ages ranging from 73 to $93 \mathrm{Ma}$ (Table 5) with relatively discordant age spectra (Fig. 11c) and large experimental errors due to the low amount of K. However, the isotope correlation diagram and the flat $\mathrm{K} / \mathrm{Ca}$ ratios do not provide evidence of excess argon (reported in the Online Fig. S1), which could indicate that ages around $90 \mathrm{Ma}$ are meaningful.

558 This suggests that early amphibole is preserved in the dated rocks, which is consistent 559 with the chemical data that point to the coexistence of primary pargasite predating synkinematic magnesio-hornblende developed around it.

\section{Interpretations and discussion}

\subsection{Nature of the protolith and subduction signature}

The sharp contact between mafic rocks and surrounding peridotites (preserved

564 from metasomatic alteration in places) suggests that these mafic rocks were emplaced, 565 prior to amphibolitization, as $100 \mathrm{~m}$-scale intrusions, most likely as dikes or melt 566 lenses. The lack of pervasive deformation in the peridotite a few meters away from 567 the shear bands, and the presence of olivine and orthopyroxene in mafic rocks, rule 568 out the possibility that the mafic bands represent sheared metamorphic sole 569 amphibolites imbricated within mantle wedge peridotites. The protolith of the mafic 570 bands is therefore interpreted as emplaced in the form of small-scale melt intrusions at 571 temperatures where peridotites were comparatively brittle. 
573 indicate that the protolith of the amphibolite bands was a norite or a troctolitic norite.

574 Late hornblende (i.e. magnesio-hornblende) and $\mathrm{Ca}-\mathrm{Na}$ plagioclase, which abound in 575 amphibolite bands, may have recrystallized from orthopyroxene, olivine and 576 anorthitic plagioclase (such as found in the "noritic" pods) during amphibolitisation 577 and/or later fluid infiltration. Clinopyroxene was either absent or is now completely 578 replaced (undeformed hornblendite dikes from Rivière des Pirogues show late 579 amphibole replacing large clinopyroxene crystals; Pirard, 2012).

Olivine-bearing domains cross-cut by olivine-free domains (Fig. 6c) point to 581 evolving compositions of the magma intruding the peridotite. The positive correlation 582 between $\mathrm{Cr} \#$ of spinel and $\mathrm{Mg} \#$ of olivine in olivine-bearing amphibolites suggests 583 that the mafic protolith formed through melting of harzburgite with a supra584 subduction signature followed by fractional crystallization (Marchesi et al., 2009). 585 The presence of orthopyroxene, plagioclase and early amphibole (i.e. pargasite) is 586 consistent with peridotite melting triggered by aqueous slab-derived fluids (Pirard, 587 2012).

Amphibolites display flat N-MORB normalized patterns with lower REE 589 abundances than N-MORB (REE Amphibolite $_{\text {/ }} \mathrm{REE}_{\mathrm{N}-\mathrm{MORB}} \sim 0.5$; Fig. 10). A simple 590 melting model shows that these amphibolites are too enriched, however, to derive 591 directly from melting of the host depleted harzburgite and require a less depleted 592 ultramafic source (either refertilized by fluids or silica-rich melts). Trace elements 593 patterns of amphibolites in fact closely fit those of unmetamorphosed microdioritic 594 dikes found in the Massif du Sud, interpreted as subduction-related magma intrusions 595 by Cluzel et al. (2006). 
597 display negative anomalies relative to REE (Fig. 10). These are characteristic of 598 subduction zone magmas, as these elements are retained in rutile and zircon in the 599 subducting slab (e.g. Coltorti et al., 2007; Zack and John, 2007). The enrichment in 600 LILE (and to a lesser extent in LREE) is also consistent with a subduction signature, 601 since LILE are mobilized during the dehydration of the upper part of the slab (e.g. 602 Pearce et al. 1984). Such enrichments are observed in metamorphic soles for Rb, Ba 603 and also $\mathrm{Pb}$ (Ishikawa et al., 2005). These enrichments cannot result from late sub604 surface alteration, since LILE and HFSE are mainly concentrated in high temperature 605 amphiboles which impose their geochemical signature in the whole rock (Fig. 10b; 606 Table 4).

607

\subsection{Petrological evolution, deformation and fluid ingression}

Field relationships and mineralogy suggest that the dark amphibolite bands and

610 the more leucrocratic noritic veins are cogenetic, with percolation apparently favored

611 towards the north. This direction is compatible with upward melt migration expected 612 at plate boundary (e.g. Matthews et al., 2015) within the mantle wedge (Fig. 2, 13a) 613 and close to the nascent crust (e.g. Pirard et al., 2013). Progressive aqueous fluid 614 infiltration and amphibolitization of the preexisting mafic bands would have 615 preferentially localized deformation in the former dikes during the first stages of the 616 Eocene subduction. Fig. 4c and Fig. 5c exemplify mafic veins with peridotite boudins. 617 Deformation localization is here closely tied with fluid infiltration, consistently with 618 the weaker rheology of amphibole and plagioclase compared to pyroxene (Homburg 619 et al., 2010) and olivine. 
Three main hydration stages can be seen in these rocks and related to

621 deformation events, as schematized in Fig. 13:

624 fluid intrusion and the major deformation stage (Fig. 13b). Whereas magnesio625 hornblende in undeformed leucocratic veins has an euhedral shape and are associated 626 to a groundmass of large plagioclase crystals (Fig. 6f), magnesio-hornblende within 627 the shear bands makes up the foliation, together with plagioclase (Fig. 6e), and 628 presents syn-kinematic texture (e.g. pressure shadow around orthopyroxene; Fig. 6e). 629 Euhedral late amphibole could be of magmatic origin, but syn-kinematically 630 deformed late amphibole has likely crystallized from an aqueous fluid. Nonetheless, 631 evolving late amphibole (and possibly plagioclase) compositions (Fig. 8c, 9b,c) 632 indicate that mafic bands underwent progressive recrystallization during fluid 633 infiltration and deformation (localized within the shear bands).

634 Although mafic bands are strongly boudinaged and folded, amphibole crystals 635 themselves are only mildly deformed. This is consistent with plagioclase being 636 weaker than amphibole (Getsinger and Hirth, 2014) and with some static 637 recrystallization after the peak of deformation. Peridotites in contact with mafic dikes 638 are also boudinaged during this stage and record hydration through the crystallization 639 of amphibole with a Mg\# around 0.92 (Fig. 9a).

640 Magnesio-hornblende (i.e. late amphibole) compositions yield pressure641 temperature conditions $3-5 \mathrm{kbar}$ and $750 \pm 50{ }^{\circ} \mathrm{C}$ (Table 2). These estimations are 642 similar to that calculated for leucodiorite dikes in the uppermost harzburgite (i.e. $3.5 \pm$ 
$6430.6 \mathrm{kbar}$ and $800 \pm 45{ }^{\circ} \mathrm{C}$; Pirard, 2012). As for metamorphic sole, the pressure

644 estimates for the dikes cannot be explained by the present ophiolite thickness.

Age constraints on amphibole reveal an age cluster at $55 \pm 2$ Ma (Fig. 12),

646 which is well defined for late amphibole. Although the closure temperature for the $647{ }^{40} \mathrm{Ar} /{ }^{39} \mathrm{Ar}$ method in hornblende is $\sim 200{ }^{\circ} \mathrm{C}$ lower than our temperature estimates for 648 amphibole formation, we interpret these ages as crystallization ages in a context of 649 fast cooling. Considering available constraints on the latest oceanic magmatic events, 650 pressure-temperature estimates and the age of the New Caledonia metamorphic sole 651 (Cluzel et al., 2012 and this study), high temperature metamorphism and cooling 652 below the closure temperature must have occurred in a very short lapse of time after 653 the Eocene subduction initiation. - (b) formation of the alkali-rich matrix:

The alkali-rich matrix is composed of an association of Ba-rich feldspar, 656 phlogopite and ortho-amphibole crystallized at the expense of pyroxene, olivine and 657 Ca-amphibole, from both the mafic and ultramafic protoliths, with less deformation 658 than during the main amphibolitization stage (Fig. 13c). This matrix points to an 659 episode of fluid ingression postdating amphibolitization, with a markedly distinct 660 fluid composition (i.e. richer in $\mathrm{K}, \mathrm{Na}$ and $\mathrm{Ba}$ ). Ortho-amphibole (anthophyllite) 661 indicates temperatures of $\sim 700 \pm 50^{\circ} \mathrm{C}$ (Chernosky and Autio, 1979, Nozaka, 2011). - (c) Late reaction with serpentine, talc, chlorite:

664 form $\mathrm{mm}$ to $\mathrm{cm}$-scale rims around mafic and peridotite boudins or cross-cut the 665 matrix (Fig. 13d). With temperatures lower than $500-600{ }^{\circ} \mathrm{C}$, according to presence 
666 of the talc-chlorite assemblage, this stage reflects the latest and coldest episode of 667 reequilibration of these shear bands.

668

\subsection{Geodynamics implications}

Both petrology and geochemistry (through the similarity to undeformed

671 amphibole-bearing dikes reported in the Massif du Sud; Cluzel et al., 2006; Pirard, 672 2012) suggest that mafic shear bands correspond to former hm- to km-scale mafic 673 intrusions emplaced in the highly refractory host harzburgite, deriving from the 674 melting of a moderately depleted mantle source fluxed by subduction-derived fluids $675 \quad($ see $\S 9.1)$. Trace element geochemistry (i.e. HFSE depletion and LILE enrichment) and age constraints at ca. 55 Ma (Fig. 12) show that secondary amphibolitization coincides with the east-dipping subduction initiation preluding to obduction (Spandler et al., 1995; Cluzel et al., 2001, 2012). Fluid infiltration and at least part of the trace element enrichment could result from dehydration of the upper part of the slab (as for metamorphic sole dehydration; Ishikawa et al., 2005). In this interpretation, the shear

682 bands reported here are a direct record of early subduction processes in New 683 Caledonia, deformation and mantle metasomatism in an active subduction setting. high degree of amphibolitization affecting these mafic dikes hampers modeling the degree of partial melting of the peridotites and to constrain the exact origin of the mafic protoliths. 
(1) amphibole-bearing troctolite to norite mafic intrusions would have formed at ca. $55 \mathrm{Ma}$ as a result of the east-dipping subduction preluding to obduction, as for the relatively abundant dikes interpreted as supra-subduction and dated at ca. $55 \mathrm{Ma}$ by

693 Cluzel et al. (2006) or dikes found in the nearby Massif du Sud exposures (also 694 interpreted as Eocene, based on structural data; Pirard, 2012), both interpreted as 695 formed in a supra-subduction setting at the expense of a metasomatized, HFSE696 depleted mantle. In this view, ages at ca. 90 Ma would be attributed to excess argon.

(2) mafic intrusions would represent inherited mafic melts from the Cretaceous

698 South Loyalty basin accretion (dating back to $\geq 90$ Ma; e.g. Cluzel et al., 2012 and 699 this study), as several early amphiboles yield an age of ca. 90 Ma (Fig. 12). This 700 hypothesis is supported by the similarity with ages found in amphibole-bearing dikes 701 in the Massif du Sud by Prinzhofer (1981). Hydrous mafic melt intrusions would have 702 been emplaced possibly as a result of the west-dipping Pacific subduction, and later 703 been fluxed by fluids leading to late amphibole crystallization and ages at ca. $55 \mathrm{Ma}$ 704 (during the second, east-dipping subduction initiation). This secondary high 705 temperature event has only partially reset the ca. 90 Ma age in pargasite.

The second interpretation is favored by the lack of evidence for excess argon, 707 early amphibole (pargasite) compositions that are distinct from those of Pirard (2012), 708 and the peculiar deformation of these dikes (those of Pirard and Cluzel are not or only 709 mildly deformed).

Deformation and fluid infiltration later localized on these preexisting mafic 711 intrusions. Shear bands developed as a result of a threefold stage of fluid infiltration 712 from slab-derived fluids. These mafic bands (and the later metasomatic matrix) are 713 good witnesses of the subduction initiation processes, both in terms of fluid influx and 714 progressive deformation near the base of the obducted New Caledonia ophiolite, from 
temperatures of $800-700{ }^{\circ} \mathrm{C}$ down to less than $600{ }^{\circ} \mathrm{C}$. Localization of deformation

716 along inherited structures such as mafic dike swarms also supports the view that 717 subduction initiation is generally triggered near a preexisting weakness zone (i.e. 718 Agard et al., 2014).

\section{Conclusions}

This study focuses on strongly sheared mafic amphibolites within the uppermost mantle of the New Caledonia obducted ophiolite, near the transition zone and $\sim 50$ $100 \mathrm{~m}$ above the basal thrust contact. Using a combination of petrological, geochemical, and geochronological data, we show that these amphibolites record melting and polyphase metasomatism within the mantle wedge during the early history of the subduction.

Shear bands indicate that deformation and high temperature fluid infiltration (from $\sim 800$ to $\sim 500{ }^{\circ} \mathrm{C}$ ) localized along preexisting hm-scale mafic intrusions emplaced within the upper mantle of the New Caledonia ophiolite and derived from peridotites refertilized by slab-derived fluids in a supra-subduction zone environment.

731 The timing of these melt intrusions remains uncertain. Age constraints on early 732 amphibole at ca. $90 \mathrm{Ma}$ and the lack of evidence for argon excess suggest that they 733 could be inherited from the former west-dipping Pacific subduction.

734 Secondary deformation and amphibolitization of these mafic dikes were the 735 result of a threefold infiltration of slab-derived fluids. The age cluster of amphibole at 736 ca. $55 \mathrm{Ma}$ indicates that amphibolitization of the mafic protoliths (as well as later 737 alkali-metasomatism) relate to the onset of the Eocene east-dipping subduction 738 initiation preluding to the obduction of the New Caledonia ophiolite. 
740 influx, progressive deformation and peridotites refertilization during subduction

741 initiation, showing how $\mathrm{m}$ - to hm-scale heterogeneities (inherited or early-emplaced

742 magmatic dikes) localize deformation and metasomatism in the oceanic lithosphere.

743 In turn this suggests that similar small-scale heterogeneities may have controlled the

744 development of larger thrusts, ultimately leading to the tectonic slicing (and later 745 emplacement) of the New Caledonia ophiolite.

746

\section{Acknowledgments}

748 We thank M. Ulrich (IPGS, France) for interesting discussions. We also thank 749 B. Caron and O. Boudouma (ISTeP-UPMC, France), M. Fialin and N. Rividi 750 (CAMPARIS), F. Le Cornec (IRD Bondy, France) and D. Deldicque (ENS Paris, 751 France) for analytical support, M. Moroni (ISTeP-UPMC) for the scanning of thin752 sections. C. Pirard and J. Hermann are warmly thanked for their constructive reviews 753 and suggestions, and Marco Scambelluri for his editorial handling. This work was 754 essentially funded through the ONLAP project (ANR blanche, SIMI6; 2010 BLAN 755615 01). Additional support was provided by an IUF grant (Institut universitaire de 756 France) to Philippe Agard.

758 References 
Agard, P., Zuo, X., Funiciello, F., Bellahsen, N., Faccenna, C., \& Savva, D., 2014. Obduction: Why, how and where. Clues from analog models. Earth and Planetary Science Letters 393, 132-145. doi:10.1016/j.epsl.2014.02.021

Aitchison, J. C., Clarke, G. L., Meffre, S., \& Cluzel, D., 1995. Eocene arc-continent collision in New Caledonia and implications for regional southwest Pacific tectonic evolution. Geology 23 (2), 161-164. doi:10.1130/0091-7613

Anderson, J. L., \& Smith, D. R., 1995. The effects of temperature and $\mathrm{fO}_{2}$ on the Al-in-hornblende barometer. American Mineralogist, 80, 549-559.

Boschi, C., Früh-Green, G. L., Delacour, A., Karson, J. A., \& Kelley, D. S., 2006. Mass transfer and fluid flow during detachment faulting and development of an oceanic core complex, Atlantis Massif (MAR $\left.30^{\circ} \mathrm{N}\right)$. Geochemistry, Geophysics, Geosystems 7. doi:10.1029/2005GC001074

Boudier, F., Ceuleneer, G., \& Nicolas, A., 1988. Shear zones, thrusts and related magmatism in the Oman ophiolite: Initiation of thrusting on an oceanic ridge. Tectonophysics 151 (1-4), 275-296. doi:10.1016/0040-1951(88)90249-1

Carson, C., Clarke, G., \& Powell, R., 2000. Hydration of eclogite, Pam Peninsula, New Caledonia. Journal of Metamorphic Geology 18, 79-90. doi:10.1046/j.1525-1314.2000.00245.x

Ceuleneer, G., Nicolas, A., \& Boudier, F., 1988. Mantle flow patterns at an oceanic spreading The Oman peridotites record. Tectonophysics 151, 1-26. doi:10.1016/0040-1951(88)90238-7

Chernosky, J. V., \& Autio, L. K., 1979. The stability of anthophyllite in the presence of quartz. American Mineralogist, 64, 294-303.

Clarke, G. L., Aitchison, J. C., \& Cluzel, D., 2006. Eclogites and Blueschists of the Pam Peninsula, NE New Caledonia: a Reappraisal. Journal of Petrology 38 (7), 843-876. doi:10.1093/petroj/38.7.843 
784 Cluzel, D., Picard, C., C Aitchison, J., Laporte, C., Meffre, S., \& Parat, F., 1997. The Poya Nappe, ex785 "Formation des Basaltes" (New Caledonia, southwest Pacific): a Campanian to Upper 786 Palaeocene oceanic plateau obducted in the late Eocene. C. R. Acad. Sci., 324, 443-451.

787 Cluzel, D., Aitchison, J. C., \& Picard, C., 2001. Tectonic accretion and underplating of mafic terranes 788 in the Late Eocene intraoceanic fore-arc of New Caledonia (Southwest Pacific): geodynamic 789 implications. Tectonophysics 340 (1-2), 23-59. doi:10.1016/S0040-1951(01)00148-2

790 Cluzel, D., Bosch, D., Paquette, J. L., Lemennicier, Y., Montjoie, P., \& Ménot, R. P., 2005. Late 791 Oligocene post-obduction granitoids of New Caledonia: A case for reactivated subduction and 792 slab break-off. Island Arc, 14(3), 254-271. doi:10.1111/j.1440-1738.2005.00470.x

793 Cluzel, D., Meffre, S., Maurizot, P., \& Crawford, A. J., 2006. Earliest Eocene (53 Ma) convergence in 794 the Southwest Pacific: evidence from pre-obduction dikes in the ophiolite of New Caledonia. 795 Terra Nova 18 (6), 395-402. doi:10.1111/j.1365-3121.2006.00704.x

796 Cluzel, D., Jourdan, F., Meffre, S., Maurizot, P., \& Lesimple, S., 2012. The metamorphic sole of New 797 Caledonia ophiolite: $40 \mathrm{Ar} / 39 \mathrm{Ar}, \mathrm{U}-\mathrm{Pb}$, and geochemical evidence for subduction inception at a spreading ridge. Tectonics 31 (3), TC3016. doi:10.1029/2011TC003085

Coleman, R. G. (1971). Tectonic Eraplacement Upper Mantle Peridotires along Continental Edges. Journal of Geophysical Research 76 (5), 1212-1222. doi:10.1029/JB076i005p01212

801 Collot, J. Y., Malahoff, A., Recy, J., Latham, G., \& Missegue, F., 1987. Overthrust emplacement of 802 New Caledonia Ophiolite: Geophysical evidence. Tectonics 6 (3), 215-232. doi:10.1029/TC006i003p00215

804 Coltorti, M., Bonadiman, C., Faccini, B., Grégoire, M., O’Reilly, S. Y., \& Powell, W., 2007. 805 Amphiboles from suprasubduction and intraplate lithospheric mantle. Lithos 99 (1-2), 68-84. Garrett transform fault: implications for the nature of the mantle-crust transition at fast-spreading 

doi:10.1007/s004100050527

811 Dewey, J. F., \& Bird, J. M., 1971. Origin and Emplacement of the Ophiolite Suite: Appalachian 812 Ophiolites in Newfoundland. Journal of Geophysical Research 76 (14). doi:10.1029/JB076i014p03179

814 Eissen, J., Crawford, A., Cotten, J., \& Meffre, S., 1998. Geochemistry and tectonic significance of 815 basalts in the Poya Terrane, New Caledonia. Tectonophysics 284, 203-219. doi:10.1016/S0040-

Ernewein, M., Pflumio, C., \& Whitechurch, H., 1988. The death of an accretion zone as evidenced the magmatic history of the Sumail ophiolite (Oman). Tectonophysics 151, 247-274.

Gaggero, L., \& Cortosegno, L., 1997. Metamorphic evolution of oceanic gabbros: recrystallization doi:10.1016/0040-1951(88)90248-X

Getsinger, a. J., \& Hirth, G., 2014. Amphibole fabric formation during diffusion creep and the rheology of shear zones. Geology 42 (6), 535-538. doi:10.1130/G35327.1

Godard, M., Jousselin, D., \& Bodinier, J.L., 2000. Relationships between geochemistry and structure beneath a palaeo-spreading centre: a study of the mantle section in the Oman ophiolite. Earth and

Godard, M., Dautria, J.-M., \& Perrin, M., 2003. Geochemical variability of the Oman ophiolite lavas: Relationship with spatial distribution and paleomagnetic directions. Geochemistry, Geophysics, 
Homburg, J. M., Hirth, G., \& Kelemen, P. B., 2010. Investigation of the strength contrast at the Moho: A case study from the Oman Ophiolite. Geology 38 (8), 679-682. doi:10.1130/G30880.1

836

837

838

Honnorez, J., Mevel, C., \& Montigny, R., 1984. Occurrence and significance of gneissic amphibolites in the Vema fracture zone, equatorial Mid-Atlantic Ridge. Geological Society, London, Special Publications 13 (1), 121-130. doi:10.1144/GSL.SP.1984.013.01.11

Ishikawa, T., Fujisawa, S., Nagaishi, K., \& Masuda, T., 2005. Trace element characteristics of the fluid liberated from amphibolite-facies slab: Inference from the metamorphic sole beneath the Oman ophiolite and implication for boninite genesis. Earth and Planetary Science Letters 240 (2), 355377. doi:10.1016/j.eps1.2005.09.049

Jourdan, F., \& Renne, P. R., 2007. Age calibration of the Fish Canyon sanidine ${ }^{40} \mathrm{Ar} /{ }^{39} \mathrm{Ar}$ dating standard using primary K-Ar standards. Geochimica et Cosmochimica Acta 71 (2), 387-402. doi:10.1016/j.gca.2006.09.002

Lagabrielle, Y., Chauvet, A., Ulrich, M., \& Guillot, S., 2013. Passive obduction and gravity-driven emplacement of large ophiolitic sheets: The New Caledonia ophiolite (SW Pacific) as a case study? Bul. Soc. Géo. Fr., 184 (6), 545-556. doi:10.2113/gssgfbull.184.6.545

Le Mée, L., Girardeau, J., \& Monnier, C., 2004. Mantle segmentation along the Oman ophiolite fossil mid-ocean ridge. Nature 432 (7014), 167-72. doi:10.1038/nature03075

Leake, B. E., Woolley, A. R., Arps, C. E. S., Gilbert, M. C., Grice, J. D., Hawthorne, F. C., Whittaker, E. J. W., 1997. Nomenclature of amphiboles. The Canadian Mineralogist 35, 219-246.

Marchesi, C., Garrido, C. J., Godard, M., Belley, F., \& Ferré, E., 2009. Migration and accumulation of ultra-depleted subduction-related melts in the Massif du Sud ophiolite (New Caledonia). Chemical Geology 266 (3-4), 171-186. doi:10.1016/j.chemgeo.2009.06.004

Matthews, K. J., Williams, S. E., Whittaker, J. M., Müller, R. D., Seton, M., \& Clarke, G. L., 2015. Geologic and kinematic constraints on Late Cretaceous to mid Eocene plate boundaries in the southwest Pacific. Earth-Science Reviews, 140, 72-107. doi:10.1016/j.earscirev.2014.10.008 
Pearce, N. J. G., Perkins, W. T., Westgate, J. A., Jackson, S. E., Neal, C. R., Chenery, S. P., \& Gorton,

McLeod C. J., Lissenbourg J., \& Bibby L. E., 2013. "Moist MORB” axial magmatism in the Oman ophiolite: The Evidence against a mid-ocean ridge origin. Geology 41 (4), 459-462. doi:10.1130/G33904.1

Moores, E. M., Kellogg, L. H., \& Dilek, Y., 2000. Tethyan ophiolites, mantle convection, and tectonic "historical contingency": A resolution of the "ophiolite conundrum." Geological Society of America Special Paper 349.

Moutte, J., (1979). Le massif de Tiébaghi, Nouvelle Calédonie et ses gîtes de chromite. Ecole Nationale Supérieure des Mines de Paris. p. 160

Nicolas, A., 1989. Principes de Tectonique. Masson (ed.), p. 190.

Nicolas, A., Boudier, F., Ildefonse, B., \& Ball, E., 2000. Accretion of Oman and United Arab Emirates ophiolite - Discussion of a new structural map. Marine Geophyiscal Research 21, 147-179. doi:10.1023/A:1026769727917

Nozaka, T., 2011. Constraints on anthophyllite formation in thermally metamorphosed peridotites from southwestern Japan. Journal of Metamorphic Geology 29 (4), 385-398. doi:10.1111/j.15251314.2010.00921.x

Omrani, J., Agard, P., Whitechurch, H., Benoit, M., Prouteau, G., \& Jolivet, L., 2008. Arc-magmatism and subduction history beneath the Zagros Mountains, Iran: A new report of adakites and geodynamic consequences. Lithos 106 (3-4), 380-398. doi:10.1016/j.lithos.2008.09.008

Paris, J. P., Andreieff, P., \& Coudray, J., 1979. Sur l'âge Eocène supérieur de la mise en place de la nappe ophiolitique de Nouvelle-Calédonie. Compt. Rend. Acad. Sci. Paris 288, 1659-1661.

Pearce, J. A., Lippard, S. J., \& Roberts, S., 1984. Characteristics and tectonic significance of suprasubduction zone ophiolites. Geological Society, London, Special Publications 16 (1), 77-94. doi:10.1144/GSL.SP.1984.016.01.06 M. P., 1997. A Compilation of New and Published Major and Trace Element Data for NIST 
Picazo, S., Cannat, M., Delacour, A., Escartín, J., Rouméjon, S., \& Silantyev, S., 2012. Deformation associated with the denudation of mantle-derived rocks at the Mid-Atlantic Ridge $13^{\circ}-15^{\circ} \mathrm{N}$ : The role of magmatic injections and hydrothermal alteration. Geochemistry, Geophysics, Geosystems 13 (4). doi:10.1029/2012GC004121

Pirard, C., 2012. Transfer of melts in the sub-arc mantle: Insights from high-pressure experiments and from the New Caledonia ophiolite. College of Physical and Mathematical Sciences.

Pirard, C., Hermann, J., \& O’Neill, H. S. C., 2013. Petrology and Geochemistry of the Crust-Mantle Boundary in a Nascent Arc, Massif du Sud Ophiolite, New Caledonia, SW Pacific. Journal of Structures in the new caledonia peridotites-gabbros: implications for oceanic mantle and crust. Tectonophysics, 69, 85-112.

Prinzhofer, A., 1981. Structure et pétrologie d'un cortège ophiolitique: le Massif du Sud (Nouvelle Calédonie) : la transition manteau-croûte en milieu océanique. École Nationale Supérieure des

Prinzhofer, A., \& Allègre, C. J., 1985. Residual peridotites and the mechanisms of partial melting. Earth and Planetary Science Letters 74, 251-265.

Salaün, A., Villemant, B., Semet, M. P., Staudacher, T., 2010. Cannibalism of olivine-rich cumulate xenoliths during the 1998 eruption of Piton de la Fournaise (La Réunion hotspot): Implications for the generation of magma diversity. Jour. Volcanol. Geotherm. Res. 198, 187-204 doi:10.1016/j.jvolgeores.2010.08.022 
Schellart, W. P., Lister, G. S., \& Toy, V. G., 2006. A Late Cretaceous and Cenozoic reconstruction of the Southwest Pacific region: Tectonics controlled by subduction and slab rollback processes. Earth-Science Reviews, 76 (3-4), 191-233. doi:10.1016/j.earscirev.2006.01.002

Shervais, J. W., 2001. Birth, death, and resurrection: The life cycle of suprasubduction zone ophiolites. Geochemistry, Geophysics, Geosystems 2. doi:10.1029/2000GC000080

Spandler, C., Rubatto, D., \& Hermann, J., 2005. Late Cretaceous-Tertiary tectonics of the southwest Pacific: Insights from U-Pb sensitive, high-resolution ion microprobe (SHRIMP) dating of eclogite facies rocks from New Caledonia. Tectonics 24 (3). doi:10.1029/2004TC001709

Stern, R., \& Bloomer, S. H., 1992. Subduction zone infancy: Examples from the Eocene Izu-BoninMarinana and Jurassic California arcs. Bulletin of the Geological Society of America 104 (12), 1621-1636. doi:10.1130/0016-7606

Sun, S. S., \& McDonough, W. F., 1989. Chemical and isotopic systematics of oceanic basalts: implications for mantle composition and processes. Geological Society, London, Special Publications 42 (1), 313-345. doi:10.1144/GSL.SP.1989.042.01.19

Ulrich, M., Picard, C., Guillot, S., Chauvel, C., Cluzel, D., \& Meffre, S., 2010. Multiple melting stages and refertilization as indicators for ridge to subduction formation: The New Caledonia ophiolite. Lithos 115 (1-4), 223-236. doi: 10.1016/j.lithos.2009.12.011

Van De Beuque, S., Auzende, J., Lafoy, Y., Bernardel, G., Nercessian, A., Regnier, M., Exon, N., 1998. Transect sismique continu entre l'arc des Nouvelles-Hebrides de l'Australie: programme FAIJST (French Australian Seismic Transect) Continuous seismic transect between the New Hebrides Arc and the Eastern. Earth and Planetary Sciences 327, 761-768. doi:10.1016/S12518050(99)80048-2

Vaughan, A. P. M., \& Scarrow, J. H., 2003. Ophiolite obduction pulses as a proxy indicator of superplume events? Earth and Planetary Science Letters 213 (3-4), 407-416. doi:10.1016/S0012$821 \mathrm{X}(03) 00330-3$ 
932 Vitale Brovarone, A., \& Agard, P., 2013. True metamorphic isograds or tectonically sliced 933 metamorphic sequence? New high-spatial resolution petrological data for the New Caledonia 934 case study. Contributions to Mineralogy and Petrology 166 (2), 451-469. doi:10.1007/s00410013-0885-2

936 Wakabayashi, J., \& Dilek, Y., 2003. What constitutes "emplacement” of an ophiolite?: Mechanisms 937 and relationship to subduction initiation and formation of metamorphic soles. Geological Society, 938 London, Special Publications 218 (1), 427-447. doi:10.1144/GSL.SP.2003.218.01.22

939 Weissel, J. K., \& Hayes, D. E., 1977. Evolution of the Tasman Sea reappraised. Earth and Planetary $940 \quad$ Science Letters 36, 77-84. doi:10.1016/0012-821X(77)90189-3

941 Whitney, D. L., \& Evans B. W., 2010. Abbreviations for names of rock-forming minerals. American 942 Mineralogist 95, 185-197.

943 Xiong, Q., Zheng, J. P., Griffin, W. L., O’Reilly, S. Y., \& Pearson, N. J., 2014. Pyroxenite Dykes in 944 Orogenic Peridotite from North Qaidam (NE Tibet, China) Track Metasomatism and Segregation 945 in the Mantle Wedge. Journal of Petrology 55 (12), 2347-2376. doi:10.1093/petrology/egu059

946 Zack, T., \& John, T., 2007. An evaluation of reactive fluid flow and trace element mobility in 947 subducting slabs. Chemical Geology 239 (3-4), 199-216. doi:10.1016/j.chemgeo.2006.10.020 


\section{$950 \quad$ Figure 1}

951

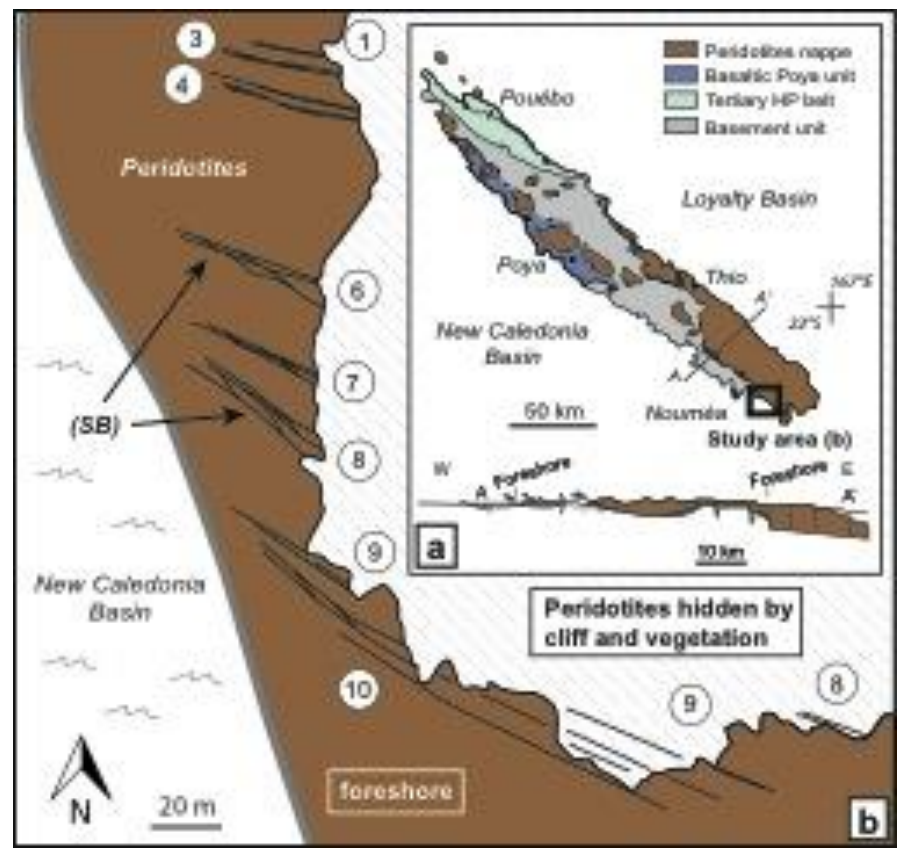

953 a) Simplified geological map and cross-section of New Caledonia Island (after Cluzel

954 et al., 2001); b) Structural map of the study area near to Plum Beach (S.E. of

955 Nouméa) showing the distribution of $\mathrm{m}$-scale shear mafic bands within the peridotite 956 of the ophiolite. Shear band (SB) \#2 is not represented at this scale. 
960

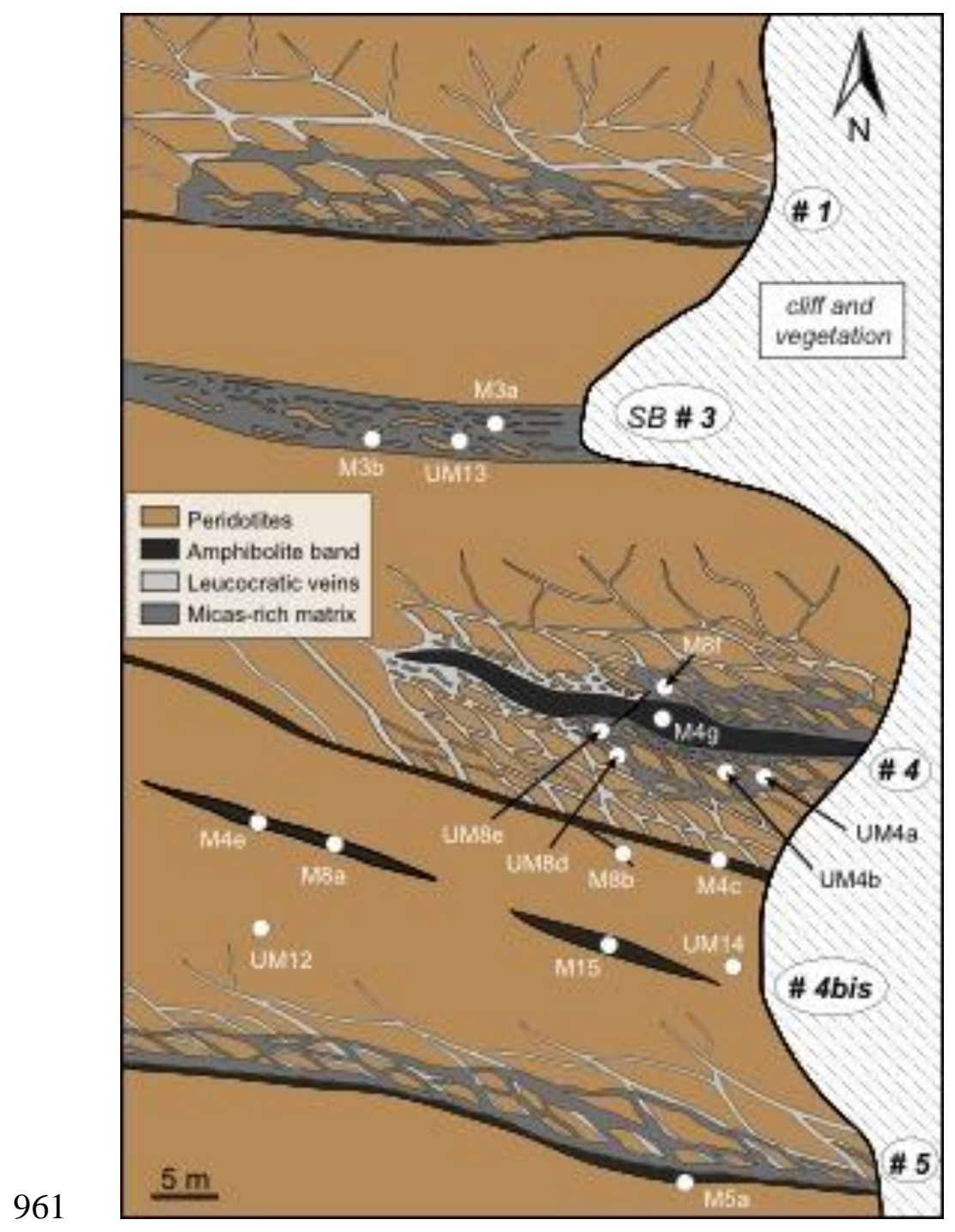

963 Structural map of the northern shear bands. Fig. 2 schematizing the relations between

964 shear bands within the undeformed peridotite of the ophiolite. White dotes indicate

965 sample location (Table 1). Shear band (SB) \#2 is not represented at this scale. 

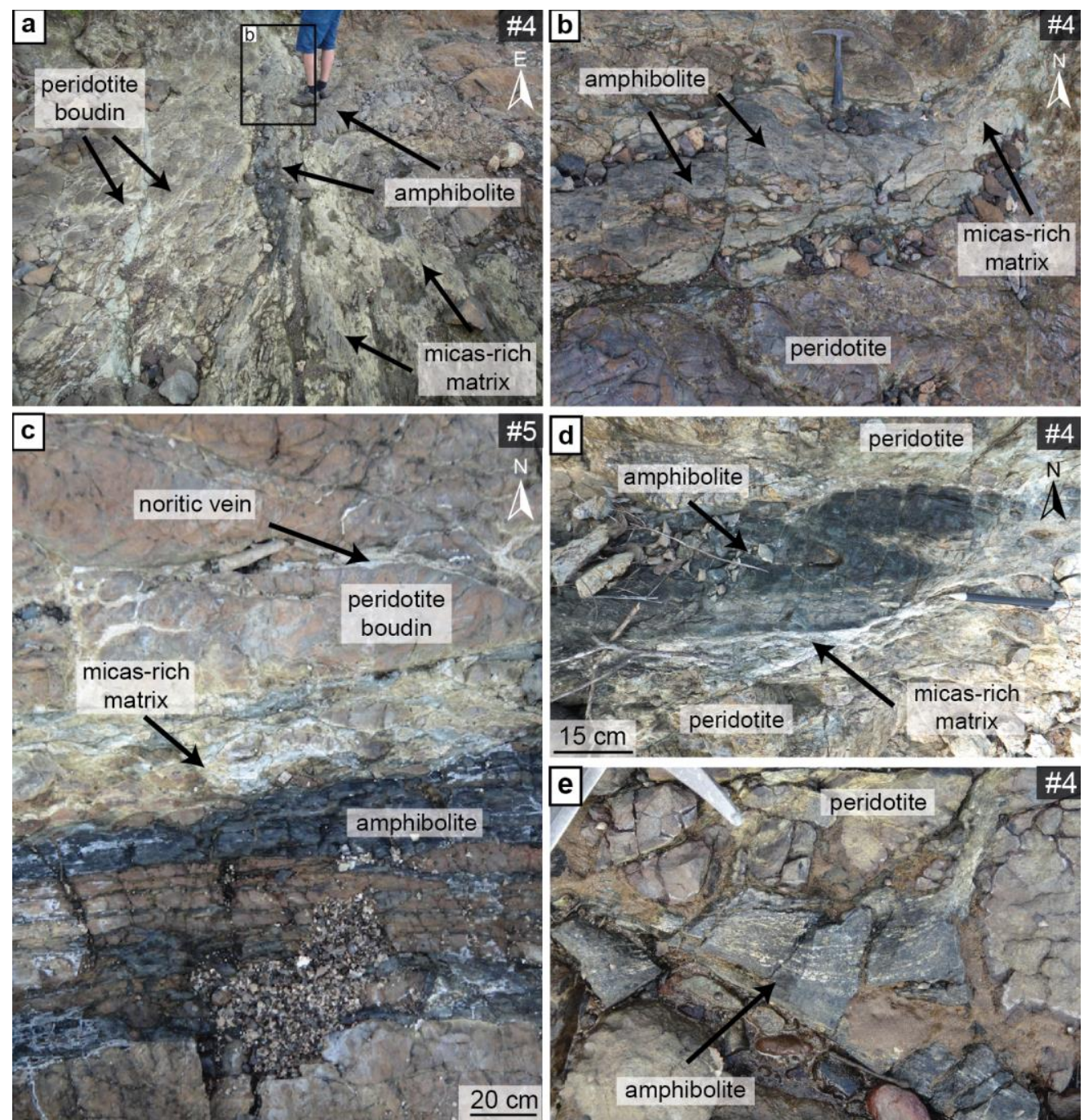

$20 \mathrm{~cm}$
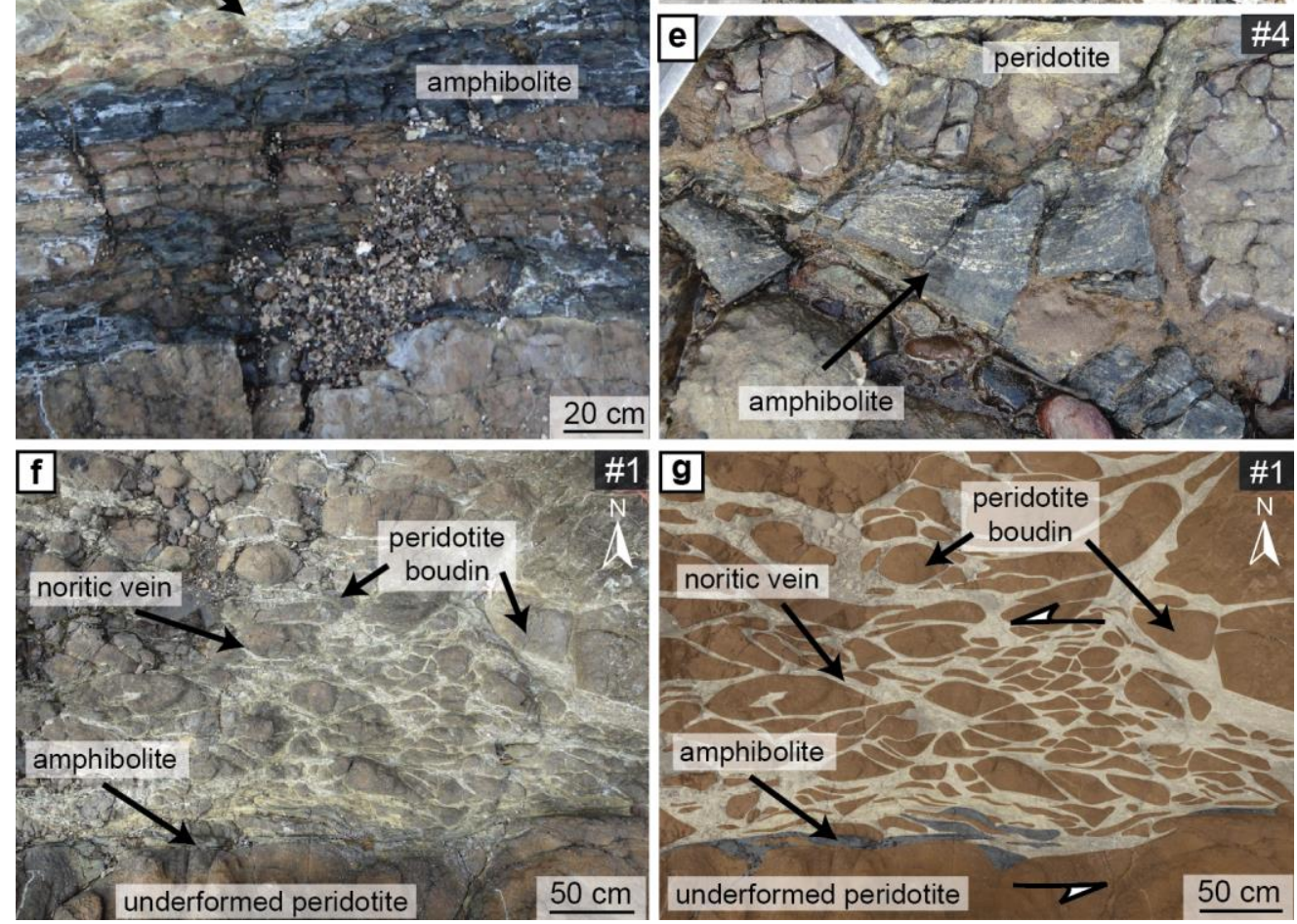

970 Structures of the mafic shear bands. Note that peridotite is highly boudinaged near

971 dark dm-scale amphibolite bands. a) Amphibolite band found at the core of shear

972 band \#4. b) A small-scale amphibolite band cut by the major amphibolite \#4. c) Shear

973 band \#5 is asymetrical. The vein network is developed only on one side of the 
974 amphibolite band (to the NE). d) and e) Boudinaged and foliated amphibolite. f) and

975 g) Photograph and corresponding schematized sketch of asymmetrical shear band \#1.

976 Vein density, thickness and length decrease away from the amphibolites. 

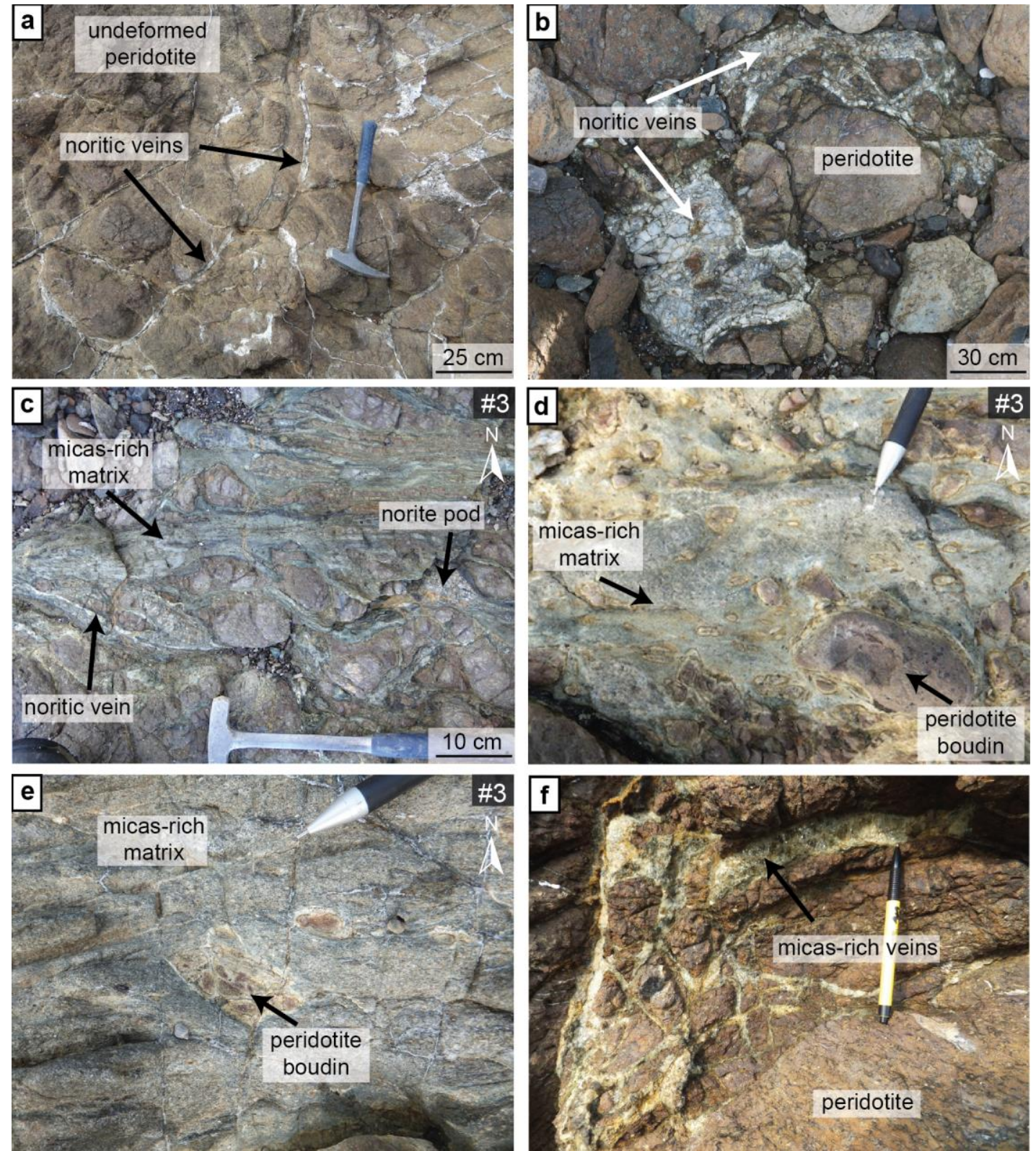

980 Photographs of the peridotite and the micas-rich matrix within and away from shear

981 bands. a) and b) Weakly deformed feldspar-rich veins within undeformed peridotites

982 away from shear bands. c), d), e) and f) Late light colored matrix with biotite,

983 chlorite, talc and serpentine minerals within the shear bands. The matrix appears to

984 form at the expense of both the mafic and ultramafic rocks. 

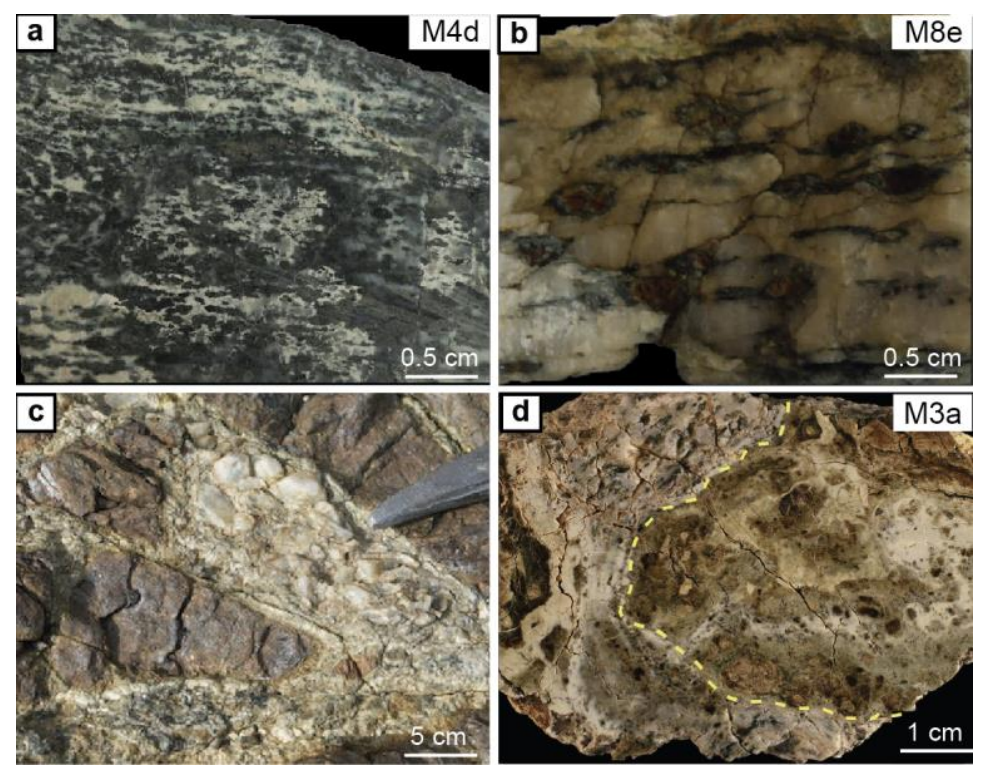

988 Representative samples of the different units observed in shear bands. a) Foliated

989 amphibolite. White layers are mainly composed of plagioclase, darker layers contains

990 amphibole and orthopyroxene. b) Feldspar-rich veins with brown coarse-grained

991 orthopyroxene rimed by green amphiboles. c) Feldspar-rich vein wrapping around a

992 peridotite boudin. Note the serpentine-bearing white rim around the boudin. d)

993 Peridotite boudin wrapped by feldspar-rich vein and cross-cut by serpentine- talc-

994 chlorite-rich white veinlets. 

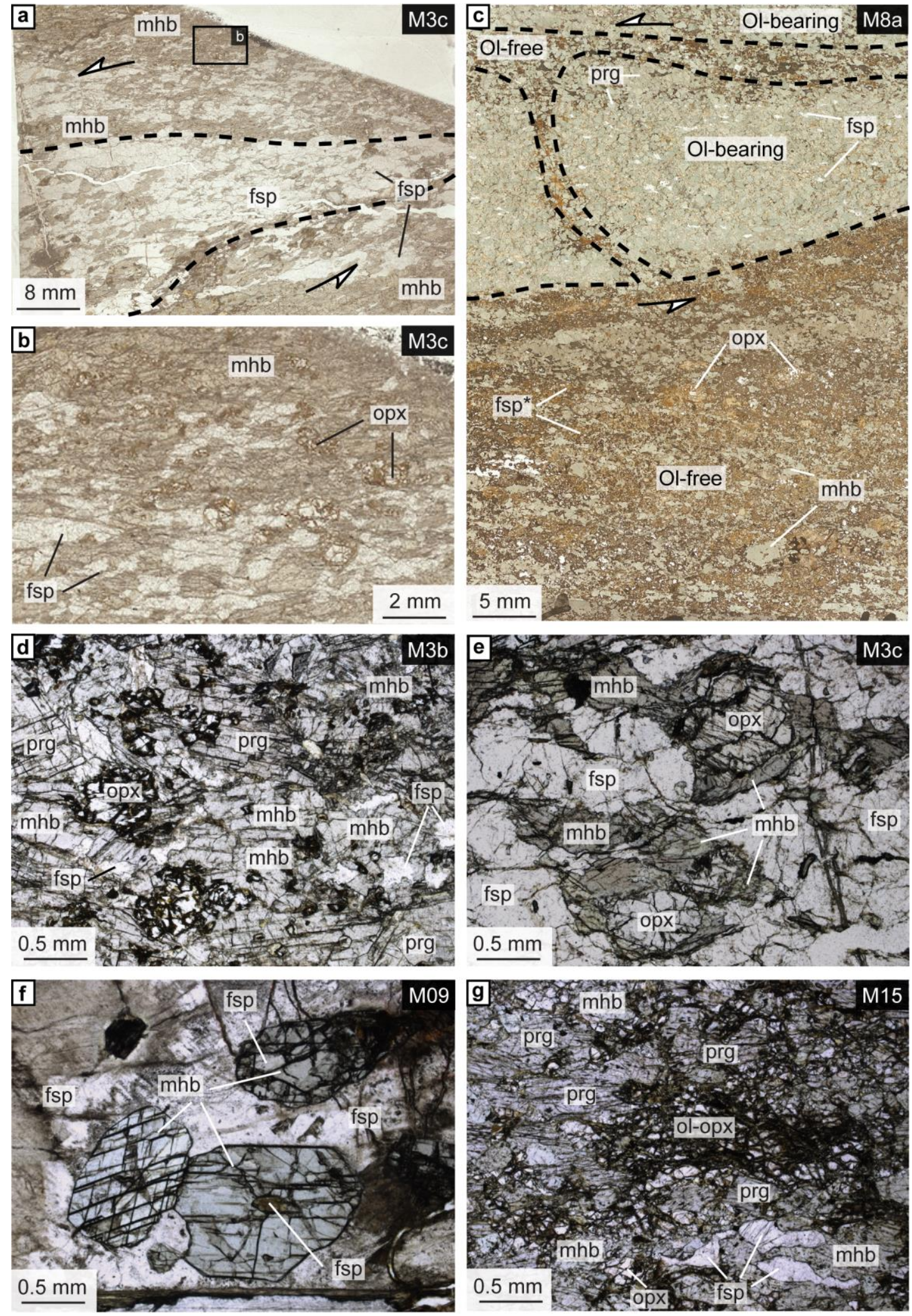
999 Representative mineral assemblages in amphibolite dikes. a) Olivine-free amphibolite 1000 with a boudinaged feldspar-rich layer within a hornblende-rich matrix. b) Zoom into 1001 the hornblende-rich matrix showing the destabilization of orthopyroxene. c) Pale 1002 olivine-bearing amphibolite band boudinaged and cross-cut by an olivine-free 1003 amphibolite layer. d) e) Assemblage of orthopyroxenes and plagioclases destabilized 1004 by the growth of amphiboles. f) Euhedral blue-pale amphibole growing in feldspar1005 rich vein away from deformation. g) Olivine, orthopyroxene and plagioclase 1006 boudinaged and destabilized by the syn-cinematic growth of amphibole. 1007 Abbreviations after Whitney and Evans (2010). 

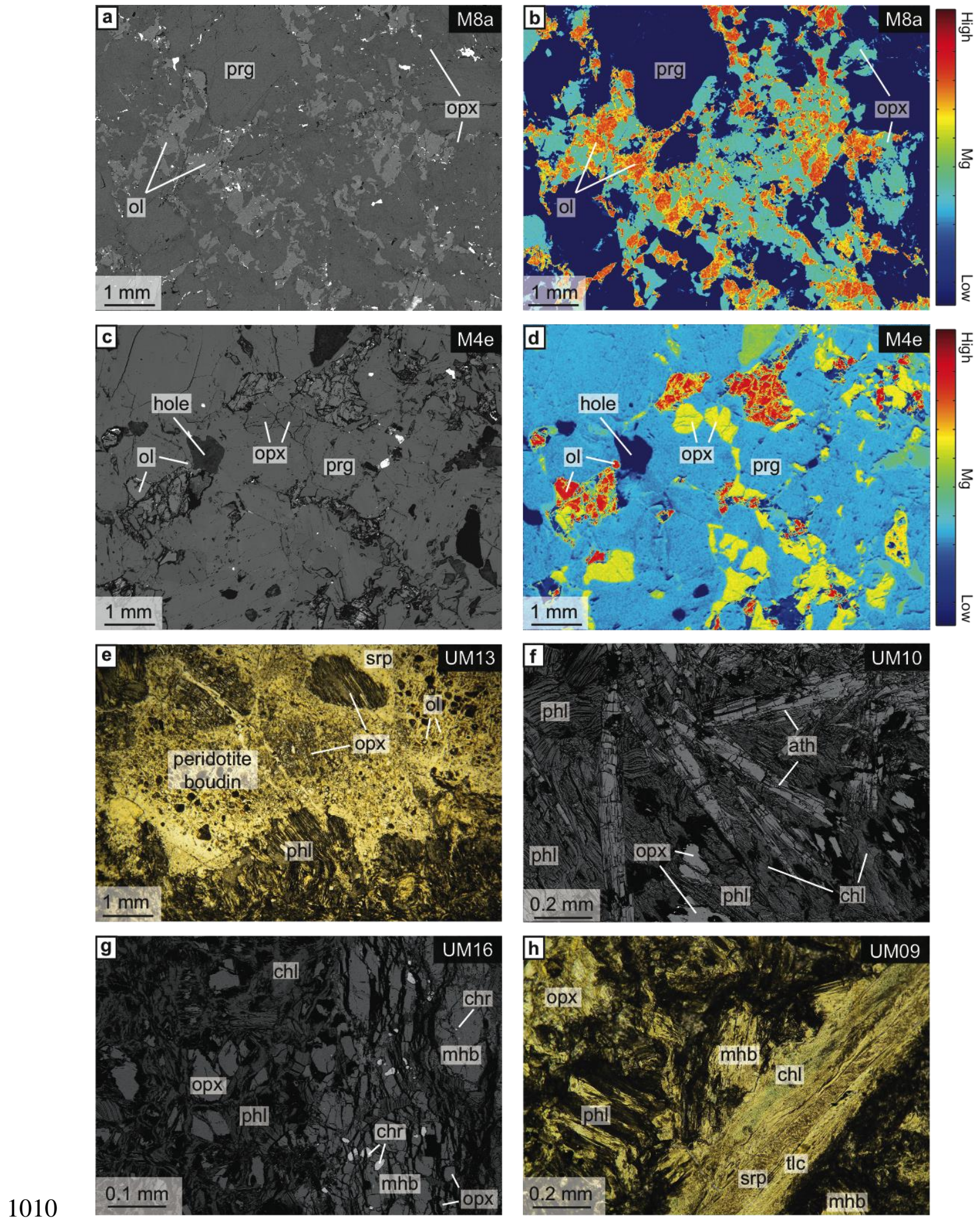

1011 Representative mineral assemblages in olivine-bearing amphibolite and in micas-rich

1012 matrix. a), b), c) and d) Olivine and plagioclase destabilized by orthopyroxene and

1013 then amphibole. a) and c) are SEM back-scattered electron images, b) and d) are 
1014 corresponding SEM abundancy maps for $\mathrm{Mg}$, where relative concentration is scaled

1015 on the right-end side color bar. e) and f) Microphotograph and SEM back-scattered

1016 electron image of peridotites boudins destabilized by the phlogopite-rich matrix

1017 associated to the anthophyllitic amphiboles. g) Coarse-grained hornblende

1018 pseudomorphing orthopyroxene and partially destabilized by phlogopite. h)

1019 Phlogopite-rich matrix cross-cut by veins of talc, chlorite and serpentine.

1020 Abbreviations after Whitney and Evans (2010).

1021

1022 

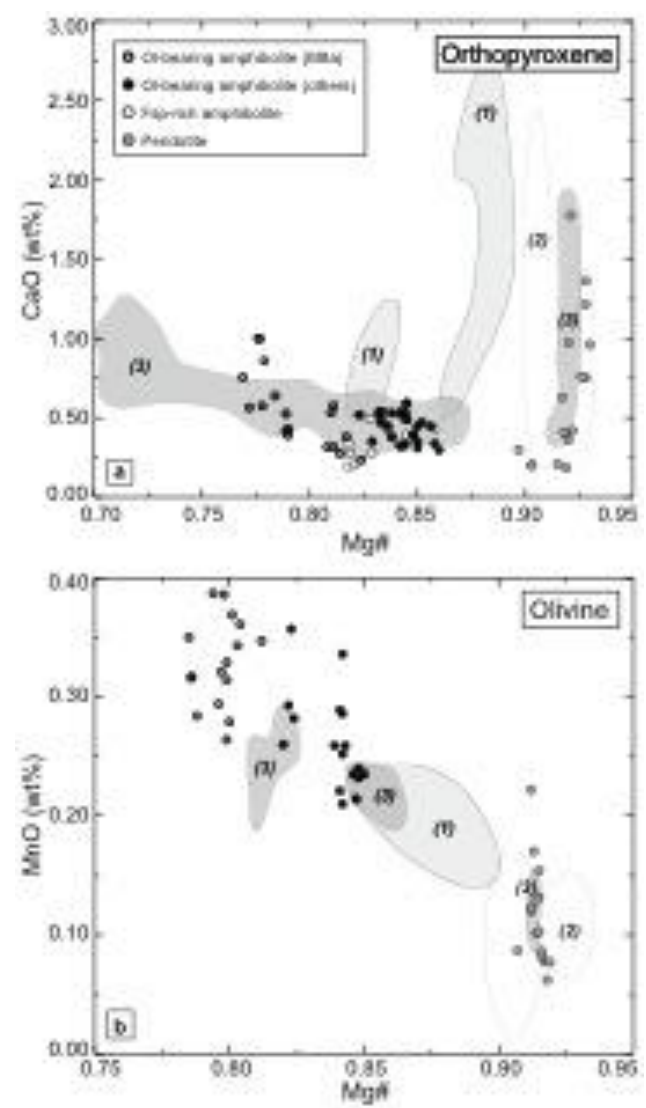

1024

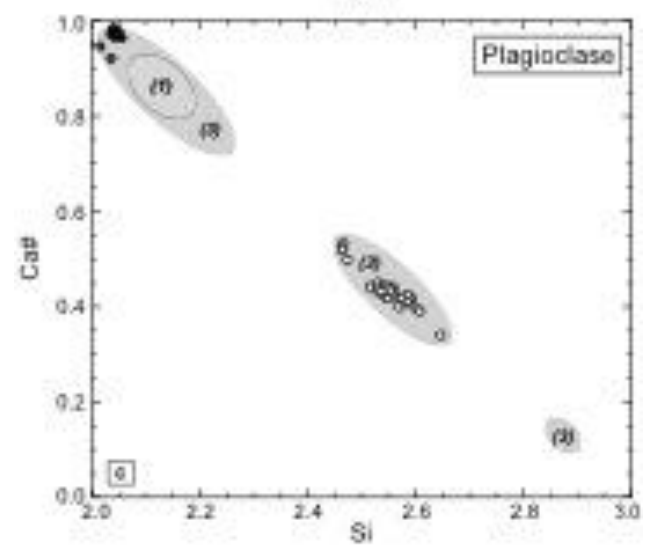

1025 EPMA composition of selected minerals. a) $\mathrm{Mg} \#[\mathrm{Mg} /(\mathrm{Mg}+\mathrm{Fe})]$ vs. $\mathrm{CaO}$ (wt\%) in 1026 mafic and ultramafic orthopyroxene. b) $\mathrm{Mg \#}$ vs. $\mathrm{MnO}$ (wt\%) in mafic and ultramafic 1027 olivine. c) $\mathrm{Si}$ (p.f.u) vs. $\mathrm{Ca} \#[\mathrm{Ca} /(\mathrm{Ca}+\mathrm{Na})]$ in plagioclase. (1) Gabbronorite sills 1028 (crustal cumulates; Pirard et al., 2013) ; (2) Peridotites from Massif du Sud (Marchesi 1029 et al., 2009) (3) Horblendite and amphibolite dikes (Pirard, 2012). 

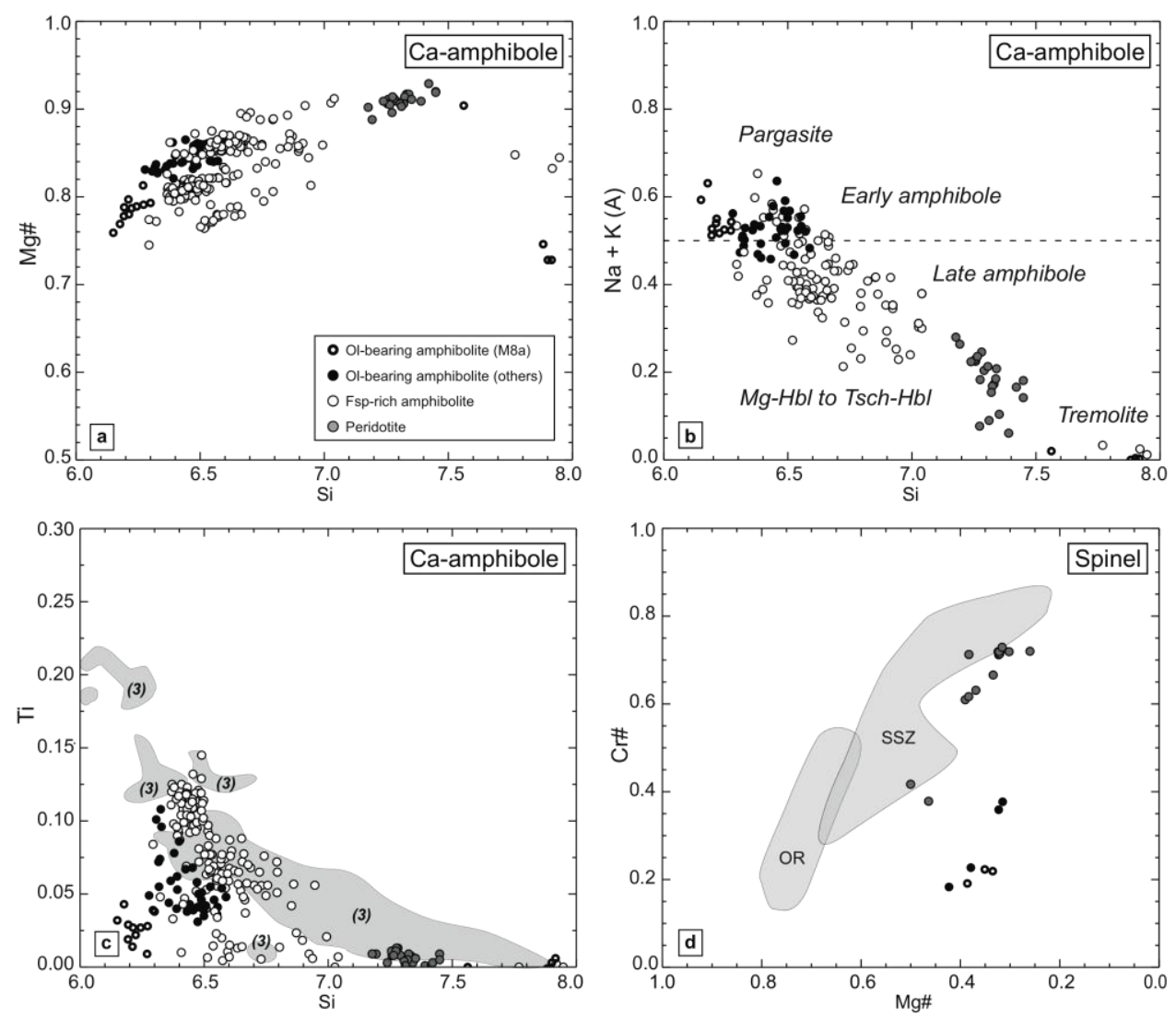

1033

1034 EPMA composition of amphibole and spinel in selected samples. a) Si (p.f.u) vs. Mg\#

1035 in Ca-amphibole. b) $\mathrm{Si}$ (p.f.u) vs. $(\mathrm{Na}+\mathrm{K})_{\mathrm{A}}$ in $\mathrm{Ca}$-amphibole after the classification of

1036 Leake et al. (1997). The dash line separates the pargasite domain (early amphibole)

1037 from the Mg-hornblende to tsch-horblende domains (late amphibole). c) Si (p.f.u) vs

1038 Ti (p.f.u) in Ca-amphibole. d) Mg\# vs. Cr\# in spinel. Or: Ocean ridge domain. SSZ:

1039 suprasubduction domain. (3) Horblendite and amphibolite dikes (Pirard, 2012) 

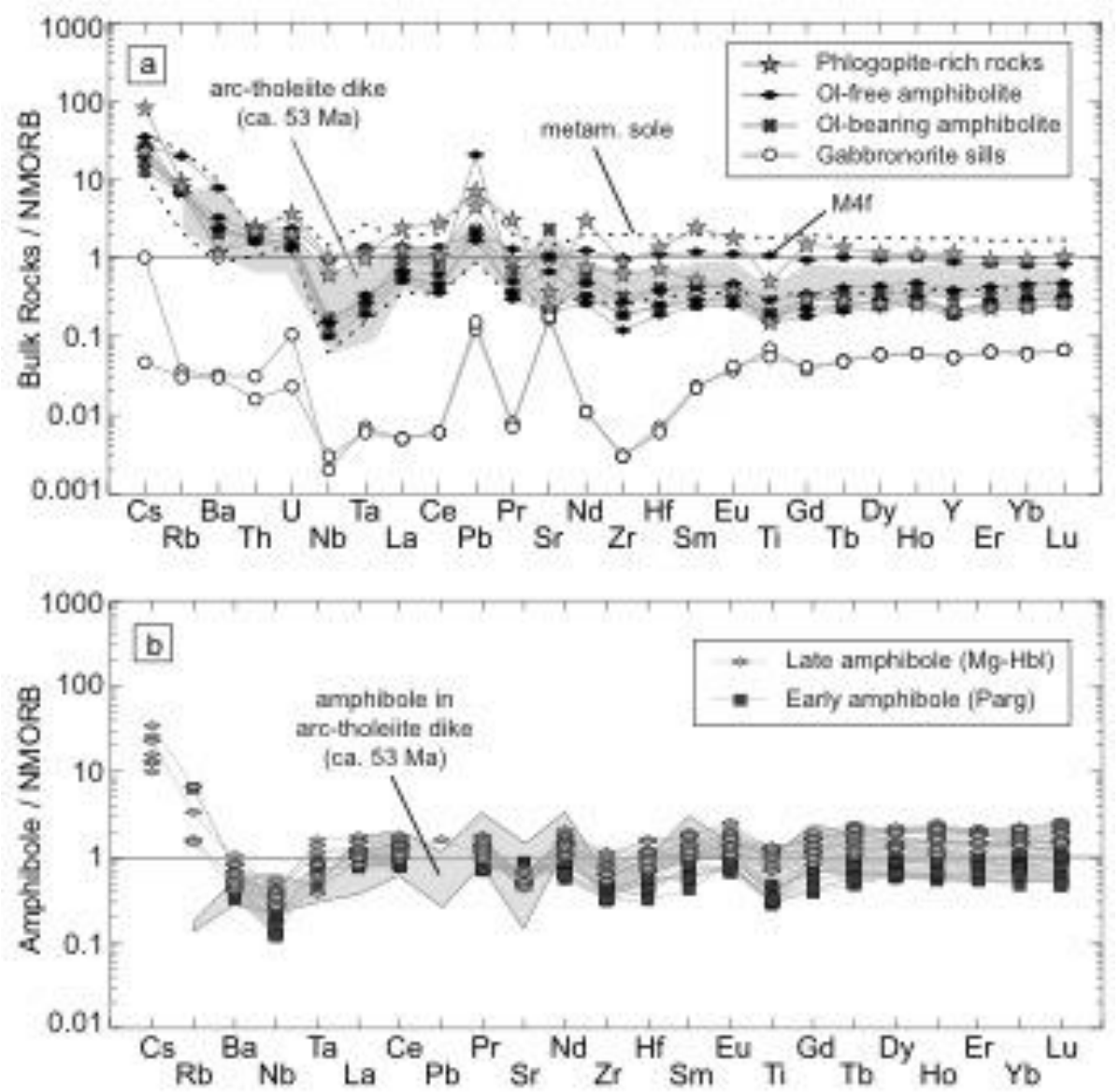

1043 (a) Trace elements concentrations of amphibolite. The N-MORB normalization values

1044 are from Sun and Mcdonough (1989). Data for the metamorphic sole are from

1045 Cluzel et al. (2012) and for pre-obduction dikes (53 Ma) from Cluzel et al. (2006).

1046 Gabbronorite sills from the crustal cumulates are from Pirard et al. (2013). (b) Trace

1047 elements spider-diagrams of hornblende in olivine-free and olivine-bearing 1048 amphibolite M8a. Normalization values for the NMORB are from Sun and 1049 Mcdonough (1989). Grey area represents the trace elements values for amphibole in 1050 hornblendite and diorite dikes described by Pirard (2012). 

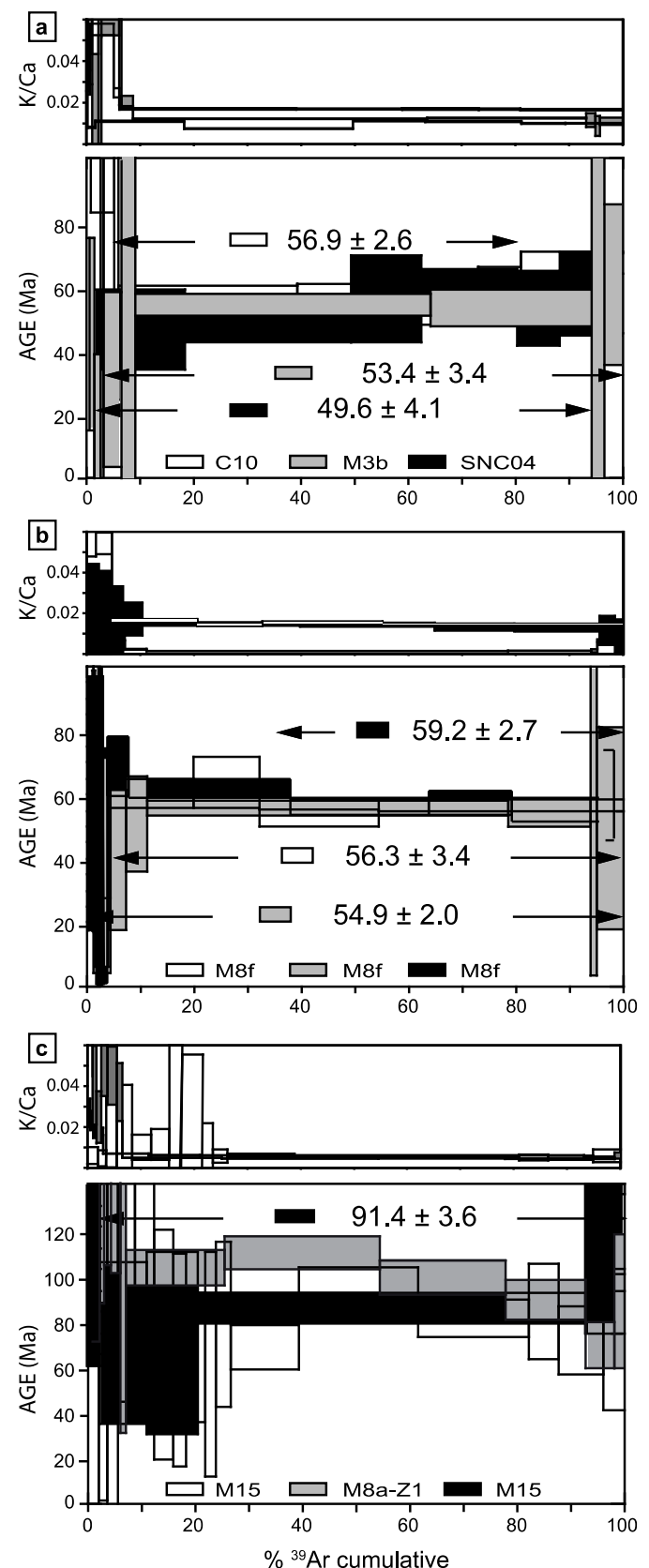

1055 Representative ${ }^{40} \mathrm{Ar} /{ }^{39} \mathrm{Ar}$ age spectra of amphibole where $\mathrm{K} / \mathrm{Ca}$ and calculated age are 1056 plotted as function of the cumulative fraction of ${ }^{39} \mathrm{Ar}$ released. Samples: C10: 1057 metamorphic sole sampled of Thio; SNC04: undeformed gabbroic dikes cross-cutting 1058 the Massif du Sud ophiolite; M8a-Z1 and M15: olivine-bearing; M8f and M3b: 1059 olivine-free amphibolite. Corresponding reverse isochron plots $\left({ }^{36} \mathrm{Ar} /{ }^{40} \mathrm{Ar}\right.$ vs. $1060{ }^{39} \mathrm{Ar} /{ }^{40} \mathrm{Ar}$ ) with intercept age are reported in the Online Fig. S1. 


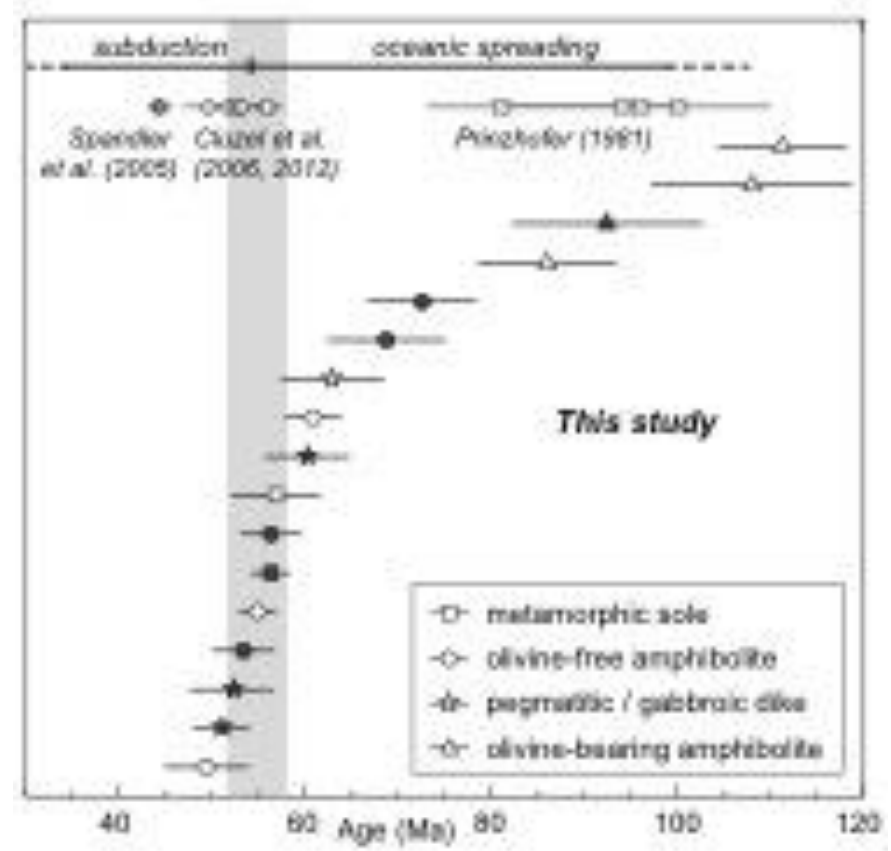

1063

1064 Plots of ${ }^{40} \mathrm{Ar} /{ }^{39} \mathrm{Ar}$ plateau age on amphibole from the different mafic units of the New

1065 Caledonia ophiolite in comparison of the timing of intrusion of pre-obduction dikes

1066 from Cluzel et al. (2006) and the metamorphic sole is from Cluzel et al. (2012). High-

1067 pressure rocks are from Spandler et al. (2005) and Cretaceous gabbroic dikes cross-

1068 cutting the peridotite are from Prinzhofer (1981). White-colored data are for ${ }^{40} \mathrm{Ar} /{ }^{39} \mathrm{Ar}$

1069 plateau ages. Black-colored data are for ${ }^{40} \mathrm{Ar} /{ }^{39} \mathrm{Ar}$ preferred ages (plateau age or

1070 intercept age). See also Table 5.

1071

1072 


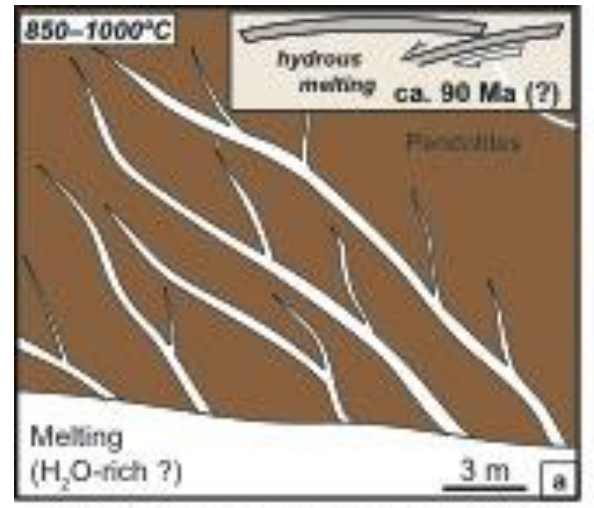

1-ca so Ma; Small-scaie meit intrusions

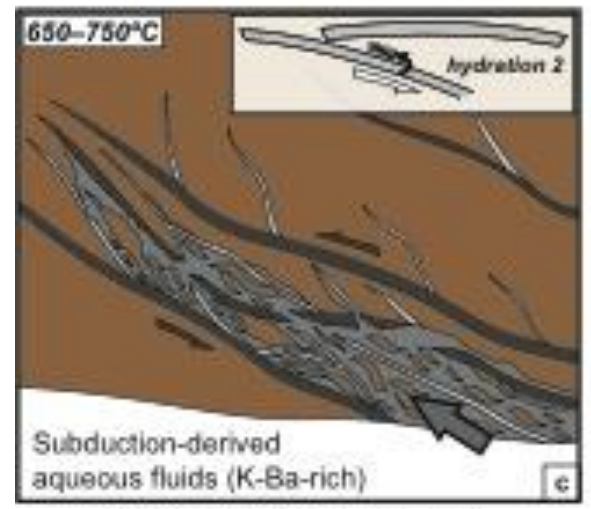

3- Main metascrnatic stage 1

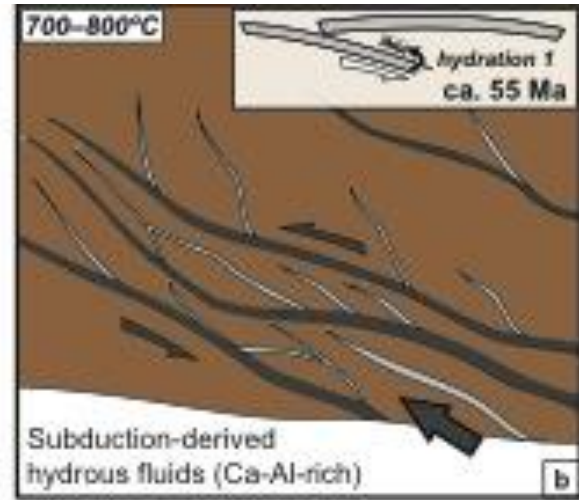

2 - ca. 55 Ma: Main deformation stage rewarking previous intrusions

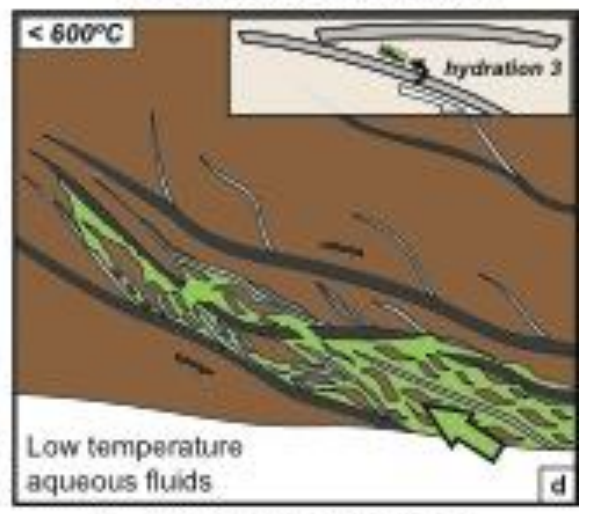

4- Main metasomatic stage 2

1075 Schematized crystallization and deformation events for the emplacement of the mafic

1076 dikes at the study area scale. The inset shows the corresponding simplified

1077 geodynamic evolution with successive stages of infiltration of subduction-related

1078 fluids. a) Small-scale melt intrusions, enriched in $\mathrm{Ca}$ and $\mathrm{Al}$ compared to the

1079 surrounding harzburgites. Fluids at the origin of these mafic veins (with

1080 orthopyroxene, olivine, plagioclase \pm early amphibole) were probably gabbroic melts

1081 derived from hydrated melting of the peridotite, caused by slab dehydration. b)

1082 Amphibolitization stage is the main deformation stage reworking previous mafic

1083 intrusions mechanically weaker than the peridotite host. Sheared amphibolites

1084 indicate that these mafic intrusions were deformed shortly after emplacement, as

1085 suggested by amphibole ages at $55 \pm 2 \mathrm{Ma}$. c) The following emplacement of the

1086 phlogopite-rich matrix records the main metasomatic stage. Anthophyllite indicates 
1087 temperature around $700{ }^{\circ} \mathrm{C}$. The intensity of deformation decreased significantly 1088 compared to b). d) Talc-chlorite-serpentine assemblage representing the last stage of 1089 metasomatism affecting the shear bands and likely starting around temperatures of $1090600^{\circ} \mathrm{C}$.

1091

1092 
1094 Figure S1
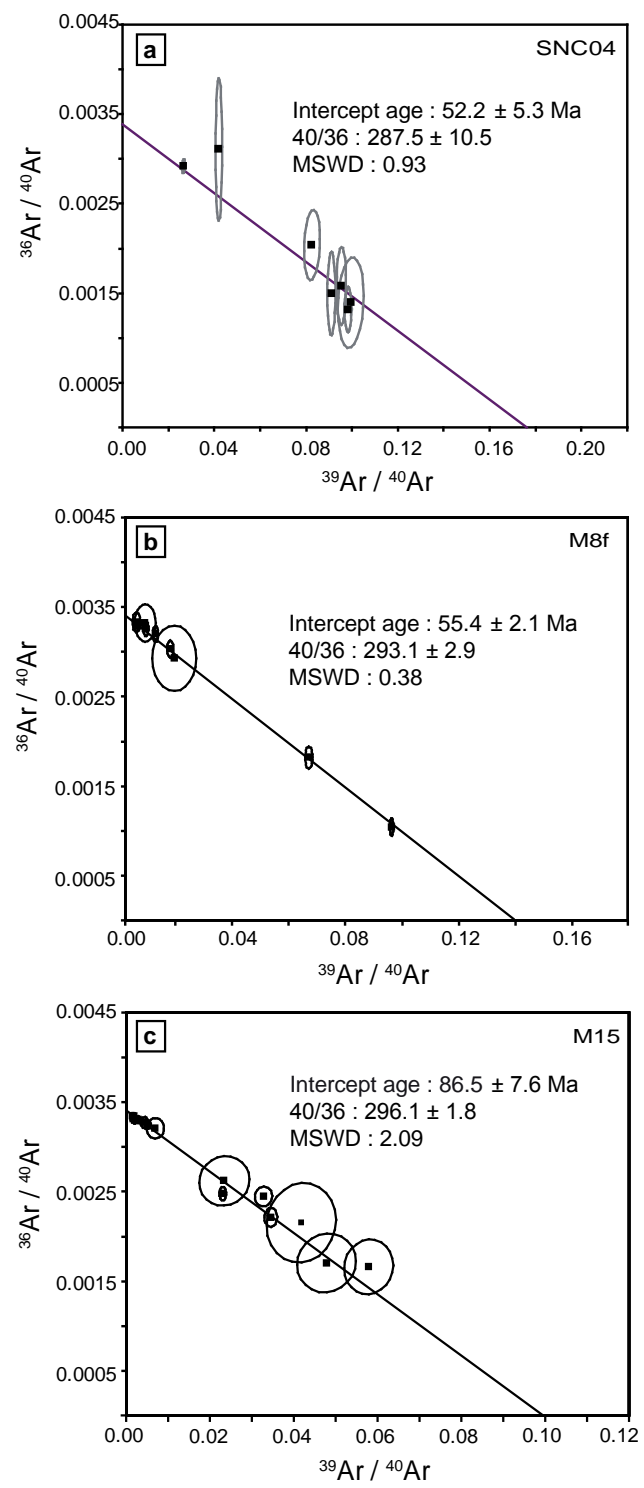

1095

1096 Corresponding reverse isochron plots $\left({ }^{36} \mathrm{Ar} /{ }^{40} \mathrm{Ar} v \mathrm{vs} .{ }^{39} \mathrm{Ar} /{ }^{40} \mathrm{Ar}\right)$ are shown for some of

1097 the measurements, with intercept age, ${ }^{36} \mathrm{Ar} /{ }^{40} \mathrm{Ar}$ ratio and final reduced chi square

1098 (MSWD). Samples: SNC04: undeformed gabbroic dikes cross-cutting the Massif du

1099 Sud ophiolite; M15: olivine-bearing amphibolite; M8f and M3b: olivine-free 1100 amphibolite. 
Table 1: Mineral occurrence for selected samples.

\begin{tabular}{|c|c|c|c|c|c|c|c|c|c|c|}
\hline Unit & Sample & ol & opx & fsp & Ba-fsp & hbl & ath & phl & $\mathrm{chl} / \mathrm{tlc}$ & $\operatorname{srp}$ \\
\hline \multirow{2}{*}{ Undeformed peridotite } & M12 & $\mathrm{x}$ & $\mathrm{x}$ & & & & & & & 1 \\
\hline & M14 & $\mathrm{x}$ & $\mathrm{x}$ & & & & & & & 1 \\
\hline \multirow{3}{*}{ Peridotite boudin } & M9 & $\mathrm{x}$ & $\mathrm{x}$ & $\mathrm{v}$ & & & o & o & 1 & 1 \\
\hline & M10 & $\mathrm{x}$ & $\mathrm{x}$ & $\mathrm{v}$ & o & o & o & o & 1 & 1 \\
\hline & M16 & $\mathrm{x}$ & $\mathrm{x}$ & $\mathrm{v}$ & & o & o & o & 1 & 1 \\
\hline \multirow{4}{*}{ Ol-bearing amphibolite } & M8a & $\mathrm{x}$ & $\mathrm{x}$ & $\mathrm{x}$ & & $\mathrm{o}$ & & & 1 & \\
\hline & M8b & $\mathrm{x}$ & $\mathrm{x}$ & $\mathrm{x}$ & & o & & & 1 & \\
\hline & M4e & $\mathrm{x}$ & $\mathrm{x}$ & $\mathrm{x}$ & & o & & & & \\
\hline & M15 & $\mathrm{x}$ & $\mathrm{x}$ & $\mathrm{x}$ & & o & & & & \\
\hline \multirow{7}{*}{ Ol-free amphibolite } & M3c & & $\mathrm{x}$ & $\mathrm{x}$ & & o & & & & \\
\hline & M3b & & $\mathrm{x}$ & $\mathrm{x}$ & & o & & & & \\
\hline & M4c & & $\mathrm{x}$ & $\mathrm{x}$ & & o & & & & \\
\hline & $\mathrm{Mx}$ & & $\mathrm{x}$ & $\mathrm{x}$ & & o & & & & \\
\hline & M4d & & $\mathrm{x}$ & $\mathrm{x}$ & & o & & 1 & 1 & \\
\hline & $\mathrm{M} 4 \mathrm{~g}$ & & $\mathrm{x}$ & $\mathrm{x}$ & & o & & 1 & 1 & \\
\hline & $8 \mathrm{e}$ & & $\mathrm{x}$ & $\mathrm{x}$ & & o & & & & \\
\hline
\end{tabular}

$\mathrm{x}$ : primary phases, $\mathrm{o}$ : secondary phases; 1 : late phases; $\mathrm{v}$ : vein wrapping peridotite boudin. Mineral abreviations after Whitney and Evans (2010). Ba-fsp: celsian. 
Table 2: Selected representative EPMA analyses for olivine, orthopyroxene, plagioclase and amphibole. Fe3+ for amphibole calculated after Leake et al. (1997)

\begin{tabular}{|c|c|c|c|c|c|c|c|c|c|c|c|c|c|}
\hline \multirow{2}{*}{$\begin{array}{l}\text { Min. } \\
\text { Samp. }\end{array}$} & \multicolumn{4}{|c|}{ Olivine } & \multicolumn{2}{|l|}{ Min. } & \multicolumn{3}{|c|}{ Orthopyroxene } & \multirow[b]{2}{*}{ M8b } & \multirow[b]{2}{*}{ M8e } & \multirow[b]{2}{*}{ UM10 } & \multirow[b]{2}{*}{ UM16 } \\
\hline & $\mathrm{M} 4 \mathrm{e}$ & M8a1 & M8b & UM10 & Samp. & M3c & M4e & M8a1 & M8a2 & & & & \\
\hline $\mathrm{SiO} 2$ & 40.05 & 39.56 & 40.24 & 41.62 & $\mathrm{SiO} 2$ & 55.85 & 55.02 & 54.51 & 54.69 & 56.04 & 55.86 & 57.44 & 58.08 \\
\hline $\mathrm{TiO} 2$ & b.d.l & b.d.l & b.d.l & b.d.l & $\mathrm{TiO} 2$ & b.d.l & b.d.l & b.d.l & b.d.l & b.d.l & 0.12 & b.d.l & b.d.l \\
\hline $\mathrm{A} 12 \mathrm{O} 3$ & b.d.l & b.d.l & b.d.l & b.d.l & $\mathrm{Al} 2 \mathrm{O} 3$ & 1.34 & 2.12 & 1.88 & 1.23 & 1.60 & 1.55 & 1.50 & 0.70 \\
\hline $\mathrm{Cr} 2 \mathrm{O} 3$ & b.d.l & b.d.l & b.d.l & b.d.l & $\mathrm{Cr} 2 \mathrm{O} 3$ & b.d.l & b.d.l & 0.08 & b.d.l & 0.07 & b.d.l & 0.72 & 0.09 \\
\hline $\mathrm{FeO}$ & 14.25 & 18.31 & 16.12 & 8.14 & $\mathrm{FeO}$ & 11.12 & 10.00 & 13.74 & 14.78 & 10.85 & 10.38 & 5.24 & 6.69 \\
\hline $\mathrm{MnO}$ & 0.23 & 0.28 & 0.36 & 0.08 & $\mathrm{MnO}$ & 0.23 & 0.25 & 0.49 & 0.42 & 0.28 & 0.25 & 0.08 & 0.11 \\
\hline $\mathrm{MgO}$ & 45.46 & 41.73 & 43.11 & 50.38 & $\mathrm{MgO}$ & 31.24 & 32.28 & 28.76 & 28.13 & 30.26 & 31.78 & 34.94 & 34.89 \\
\hline $\mathrm{CaO}$ & b.d.l & b.d.l & b.d.l & b.d.l & $\mathrm{CaO}$ & 0.28 & 0.47 & 0.53 & 0.57 & 0.54 & 0.39 & 0.42 & 0.20 \\
\hline $\mathrm{Na} 2 \mathrm{O}$ & b.d.l & b.d.l & b.d.l & b.d.l & $\mathrm{Na} 2 \mathrm{O}$ & b.d.l & b.d.l & b.d.l & b.d.l & b.d.l & b.d.l & b.d.l & b.d.l \\
\hline $\mathrm{K} 2 \mathrm{O}$ & b.d.l & b.d.l & $b . d . l$ & b.d.l & $\mathrm{K} 2 \mathrm{O}$ & b.d.l & b.d.l & b.d.l & b.d.l & b.d.l & b.d.l & b.d.l & b.d.l \\
\hline $\mathrm{BaO}$ & n.a & n.a & n.a & n.a & & n.a & n.a & n.a & n.a & n.a & n.a & n.a & n.a \\
\hline Sum & 100.0 & 99.9 & 99.8 & 100.2 & otal & 100.1 & 100.1 & 100.0 & 99.8 & 99.7 & 100.3 & 100.3 & 100.8 \\
\hline \multicolumn{14}{|c|}{ Formula unit } \\
\hline $\mathrm{Si}$ & 1.00 & 1.01 & 1.02 & 1.01 & $\mathrm{Si}$ & 1.96 & 1.92 & 1.94 & 1.96 & 1.98 & 1.95 & 1.97 & 1.99 \\
\hline $\mathrm{Ti}$ & 0.00 & 0.00 & 0.00 & 0.00 & $\mathrm{Ti}$ & 0.00 & 0.00 & 0.00 & 0.00 & 0.00 & 0.00 & 0.00 & 0.00 \\
\hline $\mathrm{Al}$ & 0.00 & 0.00 & 0.00 & 0.00 & $\mathrm{Al}$ & 0.06 & 0.09 & 0.08 & 0.05 & 0.07 & 0.06 & 0.06 & 0.03 \\
\hline $\mathrm{Cr}$ & 0.00 & 0.00 & 0.00 & 0.00 & $\mathrm{Cr}$ & 0.00 & 0.00 & 0.00 & 0.00 & 0.00 & 0.00 & 0.02 & 0.00 \\
\hline $\mathrm{Fe} 3+$ & 0.00 & 0.00 & 0.00 & 0.00 & $\mathrm{Fe} 3+$ & 0.02 & 0.08 & 0.03 & 0.02 & 0.00 & 0.02 & 0.00 & 0.00 \\
\hline $\mathrm{Fe} 2+$ & 0.30 & 0.39 & 0.34 & 0.00 & $\mathrm{Fe} 2+$ & 0.31 & 0.21 & 0.38 & 0.42 & 0.32 & 0.28 & 0.15 & 0.19 \\
\hline $\mathrm{Mn}$ & 0.00 & 0.01 & 0.01 & 0.17 & $\mathrm{Mn}$ & 0.01 & 0.01 & 0.01 & 0.01 & 0.01 & 0.01 & 0.00 & 0.00 \\
\hline $\mathrm{Mg}$ & 1.70 & 1.59 & 1.63 & 0.00 & $\mathrm{Mg}$ & 1.64 & 1.68 & 1.53 & 1.50 & 1.60 & 1.66 & 1.78 & 1.78 \\
\hline $\mathrm{Ca}$ & 0.00 & 0.00 & 0.00 & 1.82 & $\mathrm{Ca}$ & 0.01 & 0.02 & 0.02 & 0.02 & 0.02 & 0.01 & 0.02 & 0.01 \\
\hline $\mathrm{Na}$ & 0.00 & 0.00 & 0.00 & 0.00 & $\mathrm{Na}$ & 0.00 & 0.00 & 0.00 & 0.00 & 0.00 & 0.00 & 0.00 & 0.00 \\
\hline $\mathrm{K}$ & 0.00 & 0.00 & 0.00 & 0.00 & $\mathrm{~K}$ & 0.00 & 0.00 & 0.00 & 0.00 & 0.00 & 0.00 & 0.00 & 0.00 \\
\hline $\mathrm{Ba}$ & - & - & - & - & $\mathrm{Ba}$ & - & - & - & - & - & - & - & - \\
\hline $\mathrm{Mg} \#$ & 0.85 & 0.80 & 0.83 & 0.92 & $\mathrm{Mg \#}$ & 0.83 & 0.85 & 0.79 & 0.77 & 0.83 & 0.85 & 0.92 & 0.90 \\
\hline
\end{tabular}

b.d.l: below detection limit; n.a.: non analyzed 
Table 2: Selected representative EPMA analyses for olivine, orthopyroxene, plagioclase and amphibole. Fe3+ for amphibole calculated after Leake et al. (1997)

Min. Min. Orthopyroxene Feldspar

\begin{tabular}{|c|c|c|c|c|c|c|c|c|c|c|c|c|c|c|c|c|c|c|c|}
\hline Samp. & M4e & M8a1 & M8b & UM10 & amp. & M3c & $\mathrm{M} 4 \mathrm{e}$ & M8a1 & M8a2 & M8b & M8e & UM10 & UM16 & mp. & M8a1 & M8a1 & M8e & UM9 & UM10 \\
\hline $\mathrm{SiO} 2$ & 40.05 & 39.56 & 40.24 & 41.62 & $\mathrm{SiO} 2$ & 55.85 & 55.02 & 54.51 & 54.69 & 56.04 & 5.86 & 57.44 & 58.08 & $\mathrm{iiO} 2$ & 43.24 & 43.55 & 56.68 & 56.62 & 51.19 \\
\hline $\mathrm{TiO} 2$ & b.d.l & b.d.l & b.d.l & b.d.l & $\mathrm{TiO} 2$ & b.d.l & b.d.l & b.d.l & b.d.l & b.d.l & 0.12 & b.d.l & b.d.l & $\mathrm{TiO} 2$ & b.d.l & b.d.l & b.d.l & b.d.l & b.d.l \\
\hline $\mathrm{Al} 2 \mathrm{O} 3$ & b.d.l & b.d.l & b.d.l & b.d.l & $\mathrm{Al} 2 \mathrm{O} 3$ & 1.34 & 2.12 & 1.88 & 1.23 & 1.60 & 1.55 & 1.50 & 0.70 & $\mathrm{~A} 12 \mathrm{O} 3$ & 37.18 & 36.77 & 27.62 & 26.70 & 22.52 \\
\hline $\mathrm{Cr} 2 \mathrm{O} 3$ & b.d.l & b.d.l & b.d.l & b.d.l & $\mathrm{Cr} 2 \mathrm{O} 3$ & b.d.l & b.d.l & 0.08 & b.d.l & 0.07 & b.d.l & 0.72 & 0.09 & $\mathrm{r} 2 \mathrm{O} 3$ & b.d.l & b.d.l & b.d.l & b.d.l & b.d.l \\
\hline $\mathrm{FeO}$ & 14.25 & 18.31 & 16.12 & 8.14 & $\mathrm{eO}$ & 11.12 & 10.00 & 13.74 & 14.78 & 10.85 & 10.38 & 5.24 & 6.69 & $\mathrm{FeO}$ & b.d.l & b.d.l & b.d.l & b.d.l & b.d.l \\
\hline $\mathrm{MnO}$ & 0.23 & 0.28 & 0.36 & 0.08 & 10 & 0.23 & 0.25 & 0.49 & 0.42 & 0.28 & 0.25 & 0.08 & 0.11 & $\mathrm{n} \mathrm{nO}$ & b.d.l & b.d.l & b.d.l & b.d.l & b.d.l \\
\hline $\mathrm{MgO}$ & 45.46 & 41.73 & 43.11 & 50.38 & $\mathrm{MgO}$ & 31.24 & 32.28 & 28.76 & 28.13 & 30.26 & 31.78 & 34.94 & 34.89 & $\mathrm{MgO}$ & b.d.l & b.d.l & b.d.l & b.d.l & b.d.l \\
\hline $\mathrm{Na} 2 \mathrm{O}$ & b.d.l & b.d.l & b.d.l & b.d.l & $\mathrm{Na} 2 \mathrm{O}$ & b.d.l & b.d.l & b.d.l & b.d.l & b.d.l & b.d.l & b.d.l & b.d.l & $\mathrm{Na} 2 \mathrm{O}$ & 0.21 & 0.54 & 6.47 & 6.61 & 0.46 \\
\hline $\mathrm{K} 2 \mathrm{O}$ & b.d.l & b.d.l & b.d.l & b.d.l & $\mathrm{K} 2 \mathrm{O}$ & b.d.l & b.d.l & b.d.l & b.d.l & b.d.l & b.d.l & b.d.l & b.d.l & $\mathrm{K} 2 \mathrm{O}$ & b.d.l & b.d.l & b.d.l & b.d.l & 7.92 \\
\hline $\mathrm{BaO}$ & n. $a$ & n. $a$ & n.a & n.a & & n. $a$ & n.a & n.a & n.a & n. $a$ & n.a & n. $a$ & n. $a$ & & n. $a$ & n. $a$ & n. $a$ & n.a & 15.78 \\
\hline $\mathrm{um}$ & 0.0 & 9 & 9.8 & 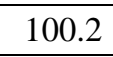 & & 100.1 & 100.1 & 100.0 & 99.8 & 99.7 & 100.3 & 100.3 & 100.8 & & .0 & 100.3 & 99.9 & 99.4 & 8.0 \\
\hline \multicolumn{20}{|l|}{ Form } \\
\hline $\mathrm{Si}$ & 1.00 & 1.01 & 1.02 & 1.01 & $\mathrm{Si}$ & 1.96 & 1.92 & 1.94 & 1.96 & 1.98 & 1.95 & 1.97 & 1.99 & S1 & 1.98 & 2.00 & 2.46 & 2.54 & 2.65 \\
\hline 1 & 0.00 & 0.00 & 0.00 & 0.00 & $\mathrm{Ti}$ & 0.00 & 0.00 & 0.00 & 0.00 & 0.00 & 0.00 & 0.00 & 0.00 & $\mathrm{Ti}$ & 0.00 & 0.00 & 0.00 & 0.00 & 0.00 \\
\hline $\mathrm{Cr}$ & 0.00 & 0.00 & 0.00 & 00 & $\mathrm{Cr}$ & 0.00 & 0.00 & 0.00 & 0.00 & 0.00 & 0.00 & 0.02 & 0.00 & C & .00 & 0.00 & 0.00 & 0.00 & 0.00 \\
\hline $3+$ & 0.00 & 0.00 & 0.00 & 00 & & 0.02 & 0.08 & 0.03 & 0.02 & 0.00 & 0.02 & 0.00 & 0.00 & & 0.00 & 0.00 & 0.00 & 0.00 & 0.00 \\
\hline Ge $2+$ & 0.30 & 0.39 & 0.34 & 0.00 & $\mathrm{Fe} 2+$ & 0.31 & 0.21 & 0.38 & 0.42 & 0.32 & 0.28 & 0.15 & 0.19 & $\mathrm{Fe} 2+$ & 0.00 & 0.00 & 0.00 & 0.00 & 0.00 \\
\hline $\mathrm{Mn}$ & 0.00 & 0.01 & 0.01 & 17 & $\mathrm{Mn}$ & 0.01 & 0.01 & 0.01 & 0.01 & 0.01 & 0.01 & 0.00 & 0.00 & & 0.00 & 0.00 & 0.00 & 0.00 & 0.00 \\
\hline $\mathrm{Mg}$ & 1.70 & 1.59 & 1.63 & 0.00 & $\mathrm{Mg}$ & 1.64 & 1.68 & 1.53 & 1.50 & 1.60 & 1.66 & 1.78 & 1.78 & $\mathrm{Mg}$ & 0.00 & 0.00 & 0.00 & 0.00 & 0.03 \\
\hline $\mathrm{Ca}$ & 0.00 & 0.00 & 0.00 & 1.82 & $\mathrm{Ca}$ & 0.01 & 0.02 & 0.02 & 0.02 & 0.02 & 0.01 & 0.02 & 0.01 & $\mathrm{Ca}$ & 1.00 & 0.95 & 0.53 & 0.46 & 0.01 \\
\hline $\mathrm{Na}$ & 0.00 & 0.00 & 0.00 & 0.00 & $\mathrm{Na}$ & 0.00 & 0.00 & 0.00 & 0.00 & 0.00 & 0.00 & 0.00 & 0.00 & $\mathrm{Na}$ & 0.02 & 0.05 & 0.48 & 0.58 & 0.05 \\
\hline $\mathrm{K}$ & 0.00 & 0.00 & 0.00 & 0.00 & $\mathrm{~K}$ & 0.00 & 0.00 & 0.00 & 0.00 & 0.00 & 0.00 & 0.00 & 0.00 & $\mathrm{~K}$ & 0.00 & 0.00 & 0.00 & 0.00 & 0.36 \\
\hline $\mathrm{Ba}$ & - & - & - & - & $\mathrm{Ba}$ & - & - & - & - & - & - & - & - & $\mathrm{Ba}$ & - & - & - & - & 0.52 \\
\hline $\mathrm{Mg \#}$ & 0.85 & 0.80 & 0.83 & 0.92 & $\mathrm{Mg} \#$ & 0.83 & 0.85 & 0.79 & 0.77 & 0.83 & 0.85 & 0.92 & 0.90 & Ca\# & 0.98 & 0.95 & 0.52 & 0.44 & 0.13 \\
\hline
\end{tabular}


Table 2 (continued)

\begin{tabular}{|c|c|c|c|c|c|c|c|c|c|c|c|c|c|c|}
\hline Min. & \multicolumn{14}{|c|}{ Amphibole } \\
\hline Samp. & $\begin{array}{l}\text { M3c } \\
\text { mhb }\end{array}$ & $\begin{array}{l}\text { M3c } \\
\text { mhb }\end{array}$ & $\begin{array}{c}\text { M8a1 } \\
\text { prg }\end{array}$ & $\begin{array}{c}\text { M8a1 } \\
\text { tr }\end{array}$ & $\begin{array}{c}\text { M8a2 } \\
\text { mhb }\end{array}$ & $\begin{array}{c}\text { M8b } \\
\text { prg }\end{array}$ & $\begin{array}{l}\text { M8e } \\
\text { mhb }\end{array}$ & $\begin{array}{l}\text { M8e } \\
\text { mhb }\end{array}$ & $\begin{array}{l}\text { M09 } \\
\text { mhb }\end{array}$ & $\begin{array}{c}\text { UM10 } \\
\text { mhb }\end{array}$ & $\begin{array}{c}\text { UM10 } \\
\text { tr }\end{array}$ & $\begin{array}{c}\text { UM10 } \\
\text { ath }\end{array}$ & $\begin{array}{c}\text { UM16 } \\
\text { mhb }\end{array}$ & $\begin{array}{c}\text { UM16 } \\
\text { tr }\end{array}$ \\
\hline $\mathrm{SiO} 2$ & 47.08 & 45.41 & 43.33 & 55.40 & 46.30 & 46.11 & 46.04 & 49.96 & 46.99 & 48.13 & 53.96 & 57.08 & 51.52 & 54.23 \\
\hline $\mathrm{TiO} 2$ & 0.19 & 1.01 & 0.40 & b.d.l & 0.79 & 0.39 & 0.06 & 0.06 & 0.68 & 0.44 & 0.07 & b.d.l & b.d.l & b.d.l \\
\hline $\mathrm{Al} 2 \mathrm{O} 3$ & 11.10 & 11.47 & 15.16 & 3.14 & 11.82 & 12.24 & 11.54 & 8.42 & 11.66 & 10.58 & 5.73 & 1.57 & 8.44 & 4.76 \\
\hline $\mathrm{Cr} 2 \mathrm{O} 3$ & b.d.l & b.d.l & b.d.l & b.d.l & 0.10 & 0.44 & b.d.l & b.d.l & b.d.l & 0.85 & b.d.l & 0.05 & b.d.l & b.d.l \\
\hline $\mathrm{FeO}$ & 7.03 & 7.38 & 8.20 & 4.16 & 8.85 & 6.11 & 7.20 & 6.32 & 5.86 & 4.09 & 3.51 & 9.14 & 3.83 & 3.05 \\
\hline $\mathrm{MnO}$ & 0.18 & 0.05 & 0.10 & 0.12 & 0.09 & 0.08 & 0.15 & 0.17 & 0.09 & 0.06 & 0.04 & 0.26 & 0.05 & 0.12 \\
\hline $\mathrm{MgO}$ & 18.26 & 17.64 & 15.27 & 21.91 & 16.08 & 17.47 & 17.55 & 19.28 & 18.88 & 19.62 & 21.81 & 28.58 & 20.97 & 22.41 \\
\hline $\mathrm{CaO}$ & 11.51 & 11.27 & 12.03 & 12.73 & 11.71 & 12.35 & 11.38 & 11.29 & 11.52 & 11.72 & 12.06 & 0.73 & 12.02 & 11.90 \\
\hline $\mathrm{Na} 2 \mathrm{O}$ & 2.20 & 2.50 & 2.80 & 0.53 & 2.13 & 2.38 & 2.47 & 1.82 & 2.20 & 2.48 & 1.26 & 0.12 & 1.67 & 1.09 \\
\hline $\mathrm{K} 2 \mathrm{O}$ & 0.12 & 0.15 & 0.10 & b.d.l & 0.06 & 0.07 & 0.13 & 0.08 & 0.13 & 0.14 & 0.05 & b.d.l & 0.08 & b.d.l \\
\hline Sum & 97.67 & 96.89 & 97.38 & 97.99 & 97.94 & 97.63 & 96.51 & 97.41 & 98.04 & 98.11 & 98.50 & 97.51 & 98.58 & 97.56 \\
\hline $\mathrm{Si}$ & 6.57 & 6.41 & 6.18 & 7.56 & 6.52 & 6.49 & 6.51 & 6.94 & 6.52 & 6.66 & 7.33 & 7.77 & 7.03 & 7.42 \\
\hline $\mathrm{Ti}$ & 0.02 & 0.11 & 0.04 & 0.00 & 0.08 & 0.42 & 0.01 & 0.01 & 0.07 & 0.05 & 0.01 & 0.00 & 0.00 & 0.00 \\
\hline $\mathrm{Al}$ & 1.83 & 1.90 & 2.55 & 0.51 & 1.96 & 2.03 & 1.92 & 1.38 & 1.90 & 1.73 & 0.92 & 0.25 & 0.97 & 0.77 \\
\hline $\mathrm{Cr}$ & 0.00 & 0.00 & 0.00 & 0.00 & 0.01 & 0.05 & 0.00 & 0.00 & 0.00 & 0.09 & 0.00 & 0.01 & 0.00 & 0.00 \\
\hline $\mathrm{Fe} 3+$ & 0.82 & 0.87 & 0.55 & 0.47 & 0.70 & 0.48 & 0.85 & 0.73 & 0.68 & 0.47 & 0.40 & 0.17 & 0.35 & 0.44 \\
\hline $\mathrm{Fe} 2+$ & 0.00 & 0.00 & 0.43 & 0.00 & 0.34 & 0.24 & 0.00 & 0.00 & 0.00 & 0.00 & 0.00 & 0.87 & 0.00 & 0.00 \\
\hline $\mathrm{Mn}$ & 0.02 & 0.01 & 0.01 & 0.01 & 0.00 & 0.01 & 0.02 & 0.02 & 0.01 & 0.01 & 0.01 & 0.03 & 0.01 & 0.01 \\
\hline $\mathrm{Mg}$ & 3.70 & 3.72 & 3.24 & 0.46 & 3.37 & 3.66 & 3.70 & 3.99 & 3.90 & 4.05 & 4.42 & 5.80 & 4.57 & 4.26 \\
\hline $\mathrm{Ca}$ & 1.72 & 1.71 & 1.84 & 1.86 & 1.77 & 1.86 & 1.73 & 1.68 & 1.71 & 1.74 & 1.76 & 0.11 & 1.75 & 1.76 \\
\hline $\mathrm{Na}$ & 0.60 & 0.69 & 0.78 & 0.14 & 0.58 & 0.65 & 0.68 & 0.49 & 0.59 & 0.66 & 0.33 & 0.03 & 0.29 & 0.44 \\
\hline $\mathrm{K}$ & 0.02 & 0.03 & 0.02 & 0.00 & 0.01 & 0.01 & 0.02 & 0.02 & 0.02 & 0.02 & 0.01 & 0.00 & 0.01 & 0.00 \\
\hline $\mathrm{Mg \#}$ & 0.82 & 0.81 & 0.77 & 0.49 & 0.76 & 0.84 & 0.81 & 0.84 & 0.86 & 0.90 & 0.92 & 0.85 & 0.93 & 0.91 \\
\hline \multicolumn{15}{|c|}{ Geothermobarometry after Holland and Blundy (1994) modified by Anderson and Smith (1995) } \\
\hline An\# & 0.52 & 0.52 & 0.95 & - & 0.52 & 0.52 & 0.52 & 0.52 & 0.44 & 0.44 & - & - & 0.44 & - \\
\hline $\mathrm{T}\left({ }^{\circ} \mathrm{C}\right)$ & 718 & 776 & 1013 & - & 756 & 963 & 739 & 702 & 680 & 677 & - & - & 615 & - \\
\hline P (kbar) & 5.16 & 4.33 & error & - & 4.98 & error & 5.23 & 3.34 & 5.97 & 3.61 & - & - & 3.78 & - \\
\hline
\end{tabular}


Table 3: Whole rock geochemistry for representative amphibolite dikes.

\begin{tabular}{|c|c|c|c|c|c|c|c|}
\hline Sample & $\begin{array}{c}\text { M15_Z1 } \\
\text { amph }\end{array}$ & $\begin{array}{c}\text { M4f } \\
\text { amph }\end{array}$ & $\begin{array}{l}\text { M15_Z2 } \\
\text { ol-amph }\end{array}$ & $\begin{array}{c}\text { M8a } \\
\text { ol-amph }\end{array}$ & $\begin{array}{c}\text { M4e } \\
\text { ol-amph }\end{array}$ & $\begin{array}{c}\text { M4a } \\
\text { amph(1) }\end{array}$ & $\begin{array}{c}\text { M4g } \\
\operatorname{amph}(1)\end{array}$ \\
\hline $\mathrm{SiO} 2$ (wt \%) & 43.83 & 49.45 & 43.61 & 44.66 & 43.09 & 46.96 & 45.81 \\
\hline $\mathrm{TiO} 2$ & 0.38 & 1.38 & 0.00 & 0.26 & 0.24 & 0.19 & 0.64 \\
\hline $\mathrm{Al} 2 \mathrm{O} 3$ & 7.41 & 14.09 & 9.35 & 10.41 & 8.94 & 7.29 & 10.13 \\
\hline $\mathrm{Fe} 2 \mathrm{O} 3$ & 9.59 & 9.78 & 11.10 & 8.12 & 9.89 & 5.88 & 5.59 \\
\hline $\mathrm{MnO}$ & 0.18 & 0.15 & 0.17 & 0.14 & 0.15 & 0.07 & 0.08 \\
\hline $\mathrm{MgO}$ & 21.54 & 8.12 & 20.99 & 20.30 & 25.40 & 25.86 & 21.90 \\
\hline $\mathrm{CaO}$ & 7.65 & 9.71 & 8.25 & 9.21 & 7.03 & 2.60 & 8.56 \\
\hline $\mathrm{Na} 2 \mathrm{O}$ & 1.42 & 3.96 & 1.70 & 1.80 & 1.61 & 1.53 & 1.61 \\
\hline $\mathrm{K} 2 \mathrm{O}$ & b.d.l. & 0.74 & b.d.l. & 0.02 & b.d.l. & 0.10 & 0.07 \\
\hline $\mathrm{P} 2 \mathrm{O} 5$ & 0.03 & 0.13 & 0.03 & 0.06 & 0.03 & 0.02 & 0.03 \\
\hline Perte 1000 & 6.41 & 1.52 & 3.16 & 4.72 & 3.54 & 9.47 & 5.21 \\
\hline Sum & 98.43 & 99.03 & 98.60 & 99.69 & 99.91 & 99.78 & 99.00 \\
\hline $\mathrm{Cr}$ (ppm) & 960.00 & 336.00 & 1249.00 & 1652.00 & 2212.00 & 1140.00 & 802.00 \\
\hline $\mathrm{Ni}$ & 348.00 & 94.00 & 523.00 & 544.00 & 819.00 & 922.00 & 648.00 \\
\hline Cs & 0.14 & 0.19 & 0.17 & 0.12 & 0.09 & 0.16 & 0.56 \\
\hline $\mathrm{Rb}$ & 3.90 & 11.10 & 4.00 & 4.00 & 3.90 & 4.40 & 5.30 \\
\hline $\mathrm{Ba}$ & 20.70 & 49.40 & 14.90 & 12.80 & 15.10 & n.d & 7.10 \\
\hline Th & 0.25 & 0.27 & 0.22 & 0.22 & 0.21 & 0.26 & 0.30 \\
\hline $\mathrm{U}$ & 0.09 & 0.11 & 0.07 & 0.08 & 0.07 & 0.09 & 0.17 \\
\hline $\mathrm{Nb}$ & 0.37 & 2.24 & 0.34 & 0.40 & 0.31 & 1.42 & 2.28 \\
\hline $\mathrm{Ta}$ & 0.04 & 0.18 & 0.05 & 0.04 & 0.03 & 0.13 & 0.16 \\
\hline $\mathrm{La}$ & 1.76 & 3.49 & 1.53 & 2.37 & 1.39 & 3.19 & 5.96 \\
\hline $\mathrm{Ce}$ & 4.56 & 10.26 & 3.48 & 6.16 & 3.29 & 8.03 & 20.82 \\
\hline $\mathrm{Pb}$ & 6.19 & 0.62 & 0.50 & 0.66 & 0.64 & 1.36 & 2.12 \\
\hline $\operatorname{Pr}$ & 0.66 & 1.72 & 0.49 & 0.90 & 0.46 & 1.22 & 4.01 \\
\hline $\mathrm{Sr}$ & 19.40 & 95.60 & 60.60 & 91.80 & 208.50 & 20.90 & 33.60 \\
\hline $\mathrm{Nd}$ & 3.45 & 9.07 & 2.42 & 4.20 & 2.25 & 5.44 & 21.72 \\
\hline $\mathrm{Zr}$ & 20.00 & 74.00 & 14.00 & 24.00 & 14.00 & 45.00 & 65.00 \\
\hline Hf & 0.80 & 2.30 & 0.51 & 0.84 & 0.49 & 1.50 & 2.72 \\
\hline $\mathrm{Sm}$ & 1.14 & 3.13 & 0.76 & 1.17 & 0.72 & 1.33 & 6.45 \\
\hline $\mathrm{Eu}$ & 0.48 & 1.15 & 0.33 & 0.43 & 0.30 & 0.39 & 1.84 \\
\hline $\mathrm{Gd}$ & 1.27 & 3.45 & 0.83 & 1.11 & 0.75 & 1.10 & 5.44 \\
\hline $\mathrm{Tb}$ & 0.28 & 0.68 & 0.17 & 0.22 & 0.16 & 0.19 & 0.90 \\
\hline Dy & 2.00 & 4.39 & 1.30 & 1.53 & 1.21 & 1.18 & 5.11 \\
\hline Ho & 0.48 & 1.00 & 0.32 & 0.37 & 0.29 & 0.26 & 1.10 \\
\hline $\mathrm{Y}$ & 11.00 & 25.00 & 6.00 & 9.00 & 6.00 & 6.00 & 32.00 \\
\hline $\mathrm{Er}$ & 1.29 & 2.51 & 0.83 & 0.97 & 0.78 & 0.68 & 2.80 \\
\hline $\mathrm{Yb}$ & 1.39 & 2.48 & 0.90 & 1.07 & 0.87 & 0.74 & 2.94 \\
\hline $\mathrm{Lu}$ & 0.22 & 0.38 & 0.15 & 0.17 & 0.14 & 0.12 & 0.47 \\
\hline
\end{tabular}

(1) mafic amphibolite altered by 1- the phlogopite-rich matrix and 2- late chlorite-rich matrix b.d.l: below detection limit 
Table 4:: LA-ICP-MS geochemistry for representative Ca-amphibole in amphibolite dikes.

\begin{tabular}{|c|c|c|c|c|c|c|}
\hline $\begin{array}{l}\text { Sample } \\
\text { Mineral }\end{array}$ & $\begin{array}{c}\text { M8a1 } \\
\text { prg }\end{array}$ & $\begin{array}{c}\text { M8a1 } \\
\text { prg }\end{array}$ & $\begin{array}{c}\text { M8a1 } \\
\text { prg }\end{array}$ & $\begin{array}{c}\text { M8a2 } \\
\text { mhb }\end{array}$ & $\begin{array}{c}\text { M8a2 } \\
\text { mhb }\end{array}$ & $\begin{array}{c}\text { M8a2 } \\
\text { mhb }\end{array}$ \\
\hline $\mathrm{SiO} 2(\mathrm{wt} \%)$ & 43.12 & 45.46 & 43.98 & 48.14 & 43.82 & 46.32 \\
\hline $\mathrm{TiO} 2$ & 0.30 & 0.09 & 0.21 & 0.53 & 0.77 & 0.85 \\
\hline $\mathrm{A} 12 \mathrm{O} 3$ & 13.99 & 12.79 & 14.11 & 10.48 & 13.13 & 11.82 \\
\hline $\mathrm{Cr} 2 \mathrm{O} 3$ & 0.07 & 0.15 & 0.24 & 0.17 & 0.10 & 0.07 \\
\hline $\mathrm{FeO}$ & 8.97 & 6.53 & 7.85 & 7.70 & 9.29 & 8.76 \\
\hline $\mathrm{MnO}$ & 0.16 & 0.07 & 0.10 & 0.13 & 0.08 & 0.06 \\
\hline $\mathrm{MgO}$ & 15.84 & 17.43 & 16.28 & 16.80 & 15.24 & 16.10 \\
\hline $\mathrm{CaO}$ & 11.83 & 12.37 & 12.12 & 11.64 & 11.89 & 12.01 \\
\hline $\mathrm{Na} 2 \mathrm{O}$ & 2.79 & 2.39 & 2.44 & 1.82 & 2.48 & 2.14 \\
\hline $\mathrm{K} 2 \mathrm{O}$ & 0.07 & 0.04 & 0.05 & 0.04 & 0.07 & 0.07 \\
\hline Sum & 97.13 & 97.31 & 97.37 & 97.47 & 96.87 & 98.20 \\
\hline Cs (ppm) & b.d.l. & b.d.l. & b.d.l. & b.d.l. & 0.24 & 0.07 \\
\hline $\mathrm{Rb}$ & b.d.l. & b.d.l. & b.d.l. & b.d.l. & 3.72 & b.d.l. \\
\hline $\mathrm{Ba}$ & 2.18 & 2.05 & 2.77 & 2.68 & 5.21 & 3.79 \\
\hline $\mathrm{Nb}$ & 0.36 & 0.31 & 0.40 & 0.68 & 0.65 & 0.87 \\
\hline $\mathrm{Ta}$ & b.d.l. & b.d.l. & b.d.l. & b.d.l. & 0.11 & 0.15 \\
\hline $\mathrm{La}$ & 2.23 & 1.90 & 2.26 & 2.57 & 2.67 & 2.81 \\
\hline $\mathrm{Ce}$ & 6.31 & 5.76 & 6.63 & 7.95 & 7.09 & 9.64 \\
\hline $\mathrm{Pb}$ & b.d.l. & b.d.l. & b.d.l. & b.d.l. & b.d.l. & b.d.l. \\
\hline $\operatorname{Pr}$ & 0.95 & 0.92 & 1.23 & 1.60 & 1.21 & 1.67 \\
\hline $\mathrm{Sr}$ & 73.11 & 68.75 & 67.36 & 41.47 & 46.78 & 48.35 \\
\hline $\mathrm{Nd}$ & 4.05 & 4.59 & 5.67 & 7.81 & 8.66 & 10.30 \\
\hline $\mathrm{Zr}$ & 24.49 & 23.12 & 30.51 & 48.31 & 38.45 & 56.43 \\
\hline $\mathrm{Hf}$ & 1.13 & 0.85 & 1.04 & 1.95 & 1.62 & 2.08 \\
\hline $\mathrm{Sm}$ & 1.50 & b.d.l. & 1.64 & 3.23 & 2.96 & 2.74 \\
\hline $\mathrm{Eu}$ & 0.87 & 0.76 & 0.81 & 1.08 & 1.09 & 1.46 \\
\hline $\mathrm{Gd}$ & b.d.l. & 1.41 & 3.34 & 3.10 & 3.62 & 6.02 \\
\hline $\mathrm{Tb}$ & 0.33 & 0.32 & 0.62 & 0.82 & 0.69 & 1.20 \\
\hline Dy & 2.76 & 2.86 & 3.86 & 5.97 & 6.50 & 8.42 \\
\hline Ho & 0.67 & 0.68 & 0.93 & 1.31 & 1.18 & 2.03 \\
\hline $\mathrm{Er}$ & 2.36 & 1.60 & 2.80 & 4.20 & 3.43 & 5.65 \\
\hline $\mathrm{Yb}$ & 2.26 & 1.44 & 2.53 & 4.72 & 4.13 & 5.58 \\
\hline $\mathrm{Lu}$ & 0.22 & 0.36 & 0.49 & 0.62 & 0.67 & 0.76 \\
\hline
\end{tabular}

See appendix for spider diagrams.

Abreviations after Whitney and Evans (2010) 
Table 5: ${ }^{40} \mathrm{Ar} /{ }^{39} \mathrm{Ar}$ age performed on amphiboles from mafic dikes cross-cutting the peridotite of the New Caledonia ophiolite.

\begin{tabular}{|c|c|c|c|c|c|c|c|c|c|c|c|}
\hline Sample & Lithology & Location & Total fusion age & Plateau age & $\%^{39} \mathrm{Ar}$ & Intercept age & $\left({ }^{40} \mathrm{Ar} /{ }^{36} \mathrm{Ar}\right)_{\mathrm{i}}$ & MSWD & Preferred age & $38 \mathrm{Ar} / 37 \mathrm{Ar}$ & $38 \mathrm{Ar} / 39 \mathrm{Ar}$ \\
\hline C10 (1) & MS amphibolite & Thio & $59.12 \pm 2.24$ & $56.21 \pm 2.14$ & 95.6 & nd & nd & $n d$ & $56.21 \pm 2.14$ & nd & $n d$ \\
\hline $\mathrm{C} 10(2)$ & MS amphibolite & Thio & $68.23 \pm 2.97$ & $56.85 \pm 4.79$ & 96.0 & $n d$ & nd & $n d$ & & nd & $n d$ \\
\hline SNC01 (1) & Pegmatite dike & Massif du Sud & $53.67 \pm 3.14$ & $60.20 \pm 4.62$ & 92.5 & nd & nd & $n d$ & $60.20 \pm 4.62$ & 0.011 & 0.41 \\
\hline SNC01 (2) & Pegmatite dike & Massif du Sud & $87.66 \pm 5.94$ & $62.87 \pm 5.54$ & 61.8 & nd & $n d$ & nd & & 0.01 & 0.36 \\
\hline SNC03 (1) & Gabbro & Massif du Sud & $51.13 \pm 4.49$ & $51.25 \pm 3.12$ & 81.5 & $51.32 \pm 4.18$ & $295.7 \pm 21.1$ & 0.65 & $51.25 \pm 3.12$ & 0.013 & 0.53 \\
\hline SNC04 (1) & Gabbro & Massif du Sud & $47.59 \pm 4.36$ & $49.56 \pm 3.98$ & 97.8 & $52.22 \pm 5.34$ & $287.5 \pm 10.5$ & 0.93 & $52.22 \pm 5.34$ & 0.007 & 0.27 \\
\hline M3b (1) & ol-free amphibolite & Plum beach & $53.64 \pm 4.27$ & $53.35 \pm 3.39$ & 78.0 & $54.10 \pm 3.40$ & $293.6 \pm 5.0$ & 1.25 & $54.10 \pm 3.40$ & 0.005 & 0.18 \\
\hline M4d (1) & ol-free amphibolite & Plum beach & $238.54 \pm 7.50$ & / & / & l & / & / & & 0.02 & 1.72 \\
\hline M4d (2) & ol-free amphibolite & Plum beach & $73.10 \pm 5.49$ & $68.67 \pm 6.37$ & 97.4 & $67.59 \pm 5.06$ & $303.7 \pm 5.0$ & 1.02 & $67.59 \pm 5.06$ & 0.02 & 1.73 \\
\hline M8f (1) & ol-free amphibolite & Plum beach & $58.34 \pm 3.61$ & $56.29 \pm 3.28$ & 95.8 & $52.86 \pm 5.34$ & $318.6 \pm 20.6$ & 1.79 & $56.23 \pm 4.42$ & nd & nd \\
\hline $\operatorname{M8f}(2)$ & ol-free amphibolite & Plum beach & $62.08 \pm 2.61$ & $60.82 \pm 3.06$ & 92.2 & $60.25 \pm 2.84$ & $299.6 \pm 4.2$ & 1.77 & & 0.004 & 0.11 \\
\hline M8f (3) & ol-free amphibolite & Plum beach & $93.78 \pm 3.08$ & $49.34 \pm 4.47$ & 49.31 & $56.46 \pm 7.40$ & $282.5 \pm 12.1$ & 0.23 & & 0.004 & 0.07 \\
\hline M8f (4) & ol-free amphibolite & Plum beach & $53.43 \pm 2.85$ & $54.86 \pm 2.04$ & 99.5 & $55.36 \pm 2.11$ & $293.1 \pm 2.9$ & 0.38 & & 0.003 & 0.08 \\
\hline M8a-Z1 (1) & ol-bearing amphibolite & Plum beach & $107.69 \pm 7.09$ & $107.94 \pm 10.80$ & 67.7 & $92.81 \pm 13.43$ & $349.1 \pm 19.0$ & 1.56 & & 0.017 & 1.71 \\
\hline M8a-Z1 (2) & ol-bearing amphibolite & Plum beach & $125.24 \pm 4.51$ & $111.22 \pm 6.93$ & 70.8 & $92.50 \pm 11.65$ & $351.7 \pm 3.7$ & 1.28 & $\begin{array}{c}92.50 \pm \\
11.65\end{array}$ & 0.017 & 1.68 \\
\hline M8a-Z2 (1) & ol-free amphibolite & Plum beach & $76.61 \pm 7.31$ & $72.54 \pm 5.83$ & 86.1 & $73.85 \pm 6.74$ & $297.0 \pm 9.6$ & 1.55 & $73.85 \pm 6.74$ & 0.024 & 1.87 \\
\hline M15 (2) & ol-bearing amphibolite & Plum beach & $81.80 \pm 4.20$ & I & l & I & I & l & & 0.019 & 1.59 \\
\hline M15 (3) & ol-bearing amphibolite & Plum beach & $89.97 \pm 8.42$ & $85.94 \pm 7.50$ & 87.9 & $86.54 \pm 7.58$ & $296.1 \pm 1.8$ & 2.09 & & 0.017 & 1.28 \\
\hline M15 (4) & ol-bearing amphibolite & Plum beach & $167.09 \pm 21.48$ & l & l & l & I & I & I & 0.013 & 1.74 \\
\hline
\end{tabular}

Preferred age is determined after plateau age, intercept age or a mean of different analysis for a same sample when the plateau age is not significant.

MS: metamorphic sole; MSWD: mean square weighted deviation. 